\title{
A Comparative Study on Research Performance of Indian Universities with NAAC A++ grade Accreditation
}

\author{
P.S. Aithal* \& Shubhrajyotsna Aithal** \\ *College of Management \& Commerce, Srinivas University, Mangalore - 575 001, India \\ OrcidID: 0000-0002-4691-8736; E-mail: psaithal@ gmail.com \\ **College of Engineering \& Technology, Srinivas University, Mangalore, India \\ OrcidID: 0000-0003-1081-5820; E-mail: shubhraaithal@ gmail.com
}

Area/Section: Education Management.

Type of the Paper: Explorative Research Analysis.

Type of Review: Peer Reviewed as per $|\mathrm{C}| \mathrm{O}|\mathrm{P}| \mathrm{E} \mid$ guidance.

Indexed in: OpenAIRE.

DOI: https://doi.org/10.5281/zenodo.5010166

Google Scholar Citation: IJMTS

\section{How to Cite this Paper:}

Aithal, P. S., \& Aithal, Shubhrajyotsna, (2021). A Comparative Study on Research Performance of Indian Universities with NAAC A++ grade Accreditation. International Journal of Management, Technology, and Social Sciences (IJMTS), 6(1), 253-285. DOI: https://doi.org/10.5281/zenodo.5010166.

International Journal of Management, Technology, and Social Sciences (IJMTS)

A Refereed International Journal of Srinivas University, India.

CrossRef DOI: https://doi.org/10.47992/IJMTS.2581.6012.0144

(C) With Author.$$
\text { (c) (7) (8) }
$$

This work is licensed under a Creative Commons Attribution-Non-Commercial 4.0 International License subject to proper citation to the publication source of the work.

Disclaimer: The scholarly papers as reviewed and published by the Srinivas Publications (S.P.), India are the views and opinions of their respective authors and are not the views or opinions of the SP. The SP disclaims of any harm or loss caused due to the published content to any party.
\end{abstract}




\title{
A Comparative Study on Research Performance of Indian Universities with NAAC A++ grade Accreditation
}

\author{
P. S. Aithal* \& Shubhrajyotsna Aithal** \\ *College of Management \& Commerce, Srinivas University, Mangalore - 575 001, India \\ OrcidID: 0000-0002-4691-8736; E-mail: psaithal@ gmail.com \\ **College of Engineering \& Technology, Srinivas University, Mangalore, India \\ OrcidID: 0000-0003-1081-5820; E-mail: shubhraaithal@gmail.com
}

\begin{abstract}
Background/Purpose: Developing and Maintaining quality in higher education is an essential aspect of the sustainability of universities. National Assessment and Accreditation Council (NAAC), India has developed a new model of HEIs assessment and accreditation from July 2017. Based on its assessment, NAAC announces the final result in the form of Cumulative Grade Point Average (CGPA) between 0 to 4.0, which is a combination of evaluation of qualitative and quantitative metrics with three parts including peer team report, graphical representation based on quantitative metric, and institutional grade sheet. Out of more than 380 universities assessment out of about 950 universities as on 30/042021, only 9 universities have been graded as $A++$ letter grade by NAAC.
\end{abstract}

Objectives: Study on Criteria wise performance of top nine A++ scored Indian Universities according to NAAC Accreditation, full scores obtained in various criteria with reasons, compare research performance and analyse it using $A B C$ model of research productivity, the effect of organizational leaders as role models on the research output, and to critically analyse the organizational SWOC based on NAAC data and outcome.

Design/Methodology/Approach: Analysis of information collected from self-study reports of $N A A C A++$ graded universities, comparing and analyzing criteria wise, and analyzing research productivity of these universities and their leaders using ABC model of annual Research performance framework.

Findings/Result: Out of nine NAAC A++ graded universities, five universities got full scores in the Curricular Aspects criterion. The universities are ranked based on their overall scores in the accreditation process. Based on the scores obtained in different criteria, the strengths and weaknesses of these universities are studied. These nine universities are further ranked based on their annual research performance and the leaders/Vice-chancellors research annual research productivity by considering the last five years research productivity. It is observed that many vice-chancellors failed to contribute to universities research outcomes as role models and motivators to other researchers of these universities. A comparative study on research performance-based grading is found to be ambiguous and little disparity is observed on key indicator-based university grading. Based on observations, some general recommendations are suggested.

Research limitations/implications: This study used the data from the Self-study Report, Peer Team Report, and Grade Report of respective universities kept for public reference in the $N A A C$ website in accordance with the new accreditation framework, downloaded on 30/04/2021.

Originality/Value: This paper compares the research performance of nine NAAC $A++$ accredited universities of India using their last 5 years' research data and identifies the strengths, weaknesses, opportunities, and challenges of these universities for further improvement.

Paper Type: Explorative Research based on research analysis.

Keywords: NAAC, A++ graded Indian universities, Annual research performance, Research role models, Self-study report, Comparative study 


\section{INTRODUCTION :}

Business is primarily seen as doing any activity for financial profit by individuals or groups of people. It is understood that providing quality aspects in the business ensure sustainable profit. Based on the type of business, four industry sectors were identified. The primary industry sector deals with doing business using naturally available resources. The secondary industry sector produces various tangible products using the output of the primary industry sector. The tertiary industry sector offers various services to customers, and the quaternary industry sector provides support services to the tertiary industry sector. Higher education offers education services to its customers and hence considered as an industry in the tertiary industry sector. Being in the service industry, the higher education industry should focus on quality services to its customers by adding values from a customer point of view. Quality higher education service helps the industry and organizations offering services under that industry to retain its existing customers for a longer period and attract new customers. Higher education has two components as teaching-training and research-innovation. Organizations which are involved in higher education services should focus on continuous improvement in quality standards of the services they provide in both teaching-training and research-innovations areas.

Since in many countries, the higher education industry is highly subsidized from public funds, the country government has a system to regulate and monitor the higher education organizations for their objectives and offerings through various regulating bodies. In India, the central government monitors the quality of services offered by higher education and research institutions and their continuous improvement through an institution called National Assessment and Accreditation Council (NAAC). NAAC was established in 1994 as an autonomous institution under University Grant Commission (UGC) and obtained mandate to conduct assessment and accreditation of HRIs to understand their quality status. Under quality status, NAAC evaluates HEIs performance related to the educational processes and outcomes, curriculum coverage, teaching-learning processes, faculty, research, infrastructure, learning resources, organisation, governance, financial well-being, and student services [1].

\section{NAAC SEVEN CRITERIA BASED FRAMEWORK :}

NAAC has developed a new model of HEIs assessment and accreditation from July 2017. Accordingly, the final result is in the form of Cumulative Grade Point Average (CGPA) between 0 to 4.0 which is a combination of evaluation of qualitative and quantitative metrics with three parts including peer team report, graphical representation based on quantitative metric, and institutional grade sheet. Table 1 lists the NAAC framework of seven criteria and key aspects for assessment and accreditation for universities offering higher education services.

Table 1 : Seven Criteria for University evaluation as per NAAC framework

\begin{tabular}{|c|c|c|c|c|}
\hline $\begin{array}{l}\text { S. } \\
\text { No }\end{array}$ & $\begin{array}{l}\text { Criteria Number \& } \\
\text { Name }\end{array}$ & $\begin{array}{l}\text { Marks } \\
\text { Allotted }\end{array}$ & $\begin{array}{l}\text { Maximum } \\
\text { Scores }\end{array}$ & Weightage for Key Indicators \\
\hline 1 & C1 - Curricular Aspects & 150 & 4.0 & $\begin{array}{l}\text { Curriculum Design and } \\
\text { Development }-50 \\
\text { Academic Flexibility }-50 \\
\text { Curriculum Enrichment - } 30 \\
\text { Feedback System - } 20\end{array}$ \\
\hline 2 & $\begin{array}{l}\mathrm{C} 2 \text { - Teaching-learning } \\
\text { and Evaluation }\end{array}$ & 200 & 4.0 & $\begin{array}{l}\text { Student Enrolment and Profile }-10 \\
\text { Catering to Student Diversity }-20 \\
\text { Teaching-Learning Process }-20 \\
\text { Teacher Profile and Quality }-50 \\
\text { Evaluation Process and Reforms - } \\
40 \\
\text { Student Performance and Learning } \\
\text { Outcomes - 30 }\end{array}$ \\
\hline 3 & $\begin{array}{l}\text { C3 - Research, } \\
\text { Innovations and } \\
\text { Extension }\end{array}$ & 250 & 4.0 & $\begin{array}{l}\text { Promotion of Research and } \\
\text { Facilities }-20 \\
\text { Resource Mobilization for Research } \\
-20\end{array}$ \\
\hline
\end{tabular}




\begin{tabular}{|c|c|c|c|c|}
\hline & & & & $\begin{array}{l}\text { Innovation Ecosystem }-30 \\
\text { Research Publications and Awards } \\
-100 \\
\text { Consultancy }-20 \\
\text { Extension Activities }-40 \\
\text { Collaboration }-20\end{array}$ \\
\hline 4 & $\begin{array}{l}\text { C4 - Infrastructure and } \\
\text { Learning Resources }\end{array}$ & 100 & 4.0 & $\begin{array}{l}\text { Physical Facilities }-30 \\
\text { Library as a Learning Resource - } \\
20 \\
\text { IT Infrastructure }-30 \\
\text { Maintenance of Campus } \\
\text { Infrastructure }-30\end{array}$ \\
\hline 5 & $\begin{array}{l}\text { C5 - Student Support } \\
\text { and Progression }\end{array}$ & 100 & 4.0 & $\begin{array}{l}\text { Student Support }-30 \\
\text { Student Progression }-40 \\
\text { Student Participation and Activities } \\
-20 \\
\text { Alumni Engagement }-10\end{array}$ \\
\hline 6 & $\begin{array}{l}\text { C6 - Governance, } \\
\text { Leadership and } \\
\text { Management }\end{array}$ & 100 & 4.0 & $\begin{array}{l}\text { Institutional Vision and Leadership } \\
-10 \\
\text { Strategy Development and } \\
\text { Deployment }-10 \\
\text { Faculty Empowerment Strategies - } \\
30 \\
\text { Financial Management and } \\
\text { Resource Mobilization - } 20 \\
\text { Internal Quality Assurance System } \\
-30\end{array}$ \\
\hline 7 & $\begin{array}{l}\text { C7 - Institutional Values } \\
\text { and Best Practices }\end{array}$ & 100 & 4.0 & $\begin{array}{l}\text { Institutional Values and Social } \\
\text { Responsibilities }-50 \\
\text { Best Practices }-30 \\
\text { Institutional Distinctiveness }-20\end{array}$ \\
\hline & Total & 1,000 & 4.0 & 1,000 \\
\hline
\end{tabular}

The Cumulative Grade Point Average (CGPA) and Letter grade as per the new evaluation model are listed in table 2. Based on this new HEIs assessment and accreditation model of evaluation of HEIs, currently (as of $31^{\text {st }}$ April 2021, about 318 universities and 5,387 colleges are evaluated and accreditation status with average cumulative grade point and letter grade are announced in NAAC, India website http://www.naac.gov.in/2-uncategorised/32-accreditation-status [1].

Table 2: NAAC evaluation outcome in terms of Cumulative Grade Point Average (CGPA) and Letter grade (with effect from July 2017)

\begin{tabular}{|l|l|l|l|l|}
\hline $\begin{array}{l}\text { S. } \\
\text { No. }\end{array}$ & $\begin{array}{l}\text { Cumulative } \\
\text { Grade Point } \\
\text { Average (CGPA) }\end{array}$ & $\begin{array}{l}\text { Letter grade \& } \\
\text { Status }\end{array}$ & $\begin{array}{l}\approx \text { Average Score out of } \\
\mathbf{1 , 0 0 0}\end{array}$ & Percentage \% \\
\hline 1 & $3.51-4.00$ & $\begin{array}{l}\text { A++ } \\
\text { (Accredited) }\end{array}$ & $876-1,000$ & $(\geq 87.6 \%)$ \\
\hline 2 & $3.26-3.50$ & $\begin{array}{l}\text { A+ } \\
\text { Accredited) }\end{array}$ & $815-875$ & $(81.5 \%-87.5 \%)$ \\
\hline 3 & $3.01-3.25$ & $\begin{array}{l}\text { A } \\
\text { Accredited) }\end{array}$ & $752.5-814$ & $(75.25 \%-81 \%)$ \\
\hline 4 & $2.76-3.00$ & $\begin{array}{l}\text { B++ } \\
\text { Accredited) }\end{array}$ & $690-750$ & $(69 \%-75 \%)$ \\
\hline 5 & $2.51-2.75$ & $\begin{array}{l}\text { B+ } \\
\text { (Accredited) }\end{array}$ & $627.5-687.5$ & $(62.75 \%-68.75 \%)$ \\
\hline 6 & $2.01-2.50$ & B & $502.5-625$ & $(50.25 \%-62.5 \%)$ \\
\hline
\end{tabular}




\begin{tabular}{|l|l|l|l|l|}
\hline & & $($ Accredited) & & \\
\hline 7 & $1.51-2.00$ & $\begin{array}{l}\text { C } \\
\text { (Accredited) }\end{array}$ & $377.5-500$ & $(37.75 \%-50 \%)$ \\
\hline 8 & $0.00-1.50$ & $\begin{array}{l}\text { D } \\
\text { (Not Accredited) }\end{array}$ & $0-375$ & $(\leq 37.5 \%)$ \\
\hline
\end{tabular}

\section{RELATED WORK AND RESEARCH AGENDA :}

Many scholarly studies have been conducted in the accreditation system on evaluating the quality of Indian higher education. The gist of such recent studies is given in table 3 . Based on this review, it is understood that a systematic study and analysis on the outcome of assessment and accreditation of topgraded universities is essential to know their merits in terms of objectives, preferences, achievements, perception on service quality, and importance given to research and publications. Accordingly, the objectives of this paper are set.

Table 3: Review of related research publications on Indian accreditation system

\begin{tabular}{|c|c|c|c|}
\hline $\begin{array}{l}\text { S. } \\
\text { No. }\end{array}$ & rea & Issues & ence \\
\hline 1 & $\begin{array}{l}\text { New Indian accreditation } \\
\text { system }\end{array}$ & $\begin{array}{l}\text { Understanding Revised NAAC } \\
\text { Grading Pattern }\end{array}$ & lhat, S. S. (2020). [2] \\
\hline 2 & $\begin{array}{l}\text { Concepts in New Indian } \\
\text { accreditation system }\end{array}$ & $\begin{array}{l}\text { Paradigm Shift in Indian Higher } \\
\text { Education Accreditation }\end{array}$ & Pati \\
\hline 3 & $\begin{array}{l}\text { Quality assessment of Indian } \\
\text { HEIs }\end{array}$ & Critical Analysis of NAAC Data & $\mathrm{Me}$ \\
\hline 4 & $\begin{array}{l}\text { Quality assessment of Indian } \\
\text { HEIs }\end{array}$ & $\begin{array}{l}\text { Impact of Accreditation on } \\
\text { Quality and Excellence of Higher } \\
\text { Education Institutions }\end{array}$ & P5] \\
\hline 5 & $\begin{array}{l}\text { Quality Initiative Reform in } \\
\text { Indian Higher Education }\end{array}$ & $\begin{array}{l}\text { Study of NAAC Accreditation } \\
\text { system }\end{array}$ & $\begin{array}{l}\text { Ghatole, S. M., et al. } \\
\text { (2021). [6] }\end{array}$ \\
\hline 6 & $\begin{array}{lr}\text { Quality } & \text { Enhancement } \\
\text { through NAAC Accreditation }\end{array}$ & State Private Universities & Iyer, S. R. (2019). [7] \\
\hline 7 & $\begin{array}{l}\text { ality Assessment of Indian } \\
\text { iversities }\end{array}$ & $\begin{array}{l}\text { cal Study of NAAC } \\
\text { n Scores }\end{array}$ & $\begin{array}{l}\text { Ravikumar, K., et al. } \\
\text { (2021). [8] }\end{array}$ \\
\hline 8 & assessment of Indian & $\begin{array}{l}\text { of Accreditation } \\
\text { NAAC and NBA }\end{array}$ & $\begin{array}{l}\text { Gholap, P., et al. } \\
\text { (2019). [9] }\end{array}$ \\
\hline 9 & $\begin{array}{l}\text { Evaluation of NAAC } \\
\text { Accreditation Criteria for the } \\
\text { Indian University }\end{array}$ & $\begin{array}{l}\text { Graph Theoretic Approach for } \\
\text { Quantitative Evaluation }\end{array}$ & $\begin{array}{l}\text { Miglani, N., et al. } \\
\text { (2017). [10] }\end{array}$ \\
\hline 10 & assessment of Indian & $\begin{array}{l}\text { of Research for } \\
\text { creditation }\end{array}$ & $\begin{array}{l}\text { N. R., et al. } \\
\text { [11] }\end{array}$ \\
\hline 11 & $\begin{array}{l}\text { NAAC Assessment and } \\
\text { Accreditation criteria }\end{array}$ & $\begin{array}{l}\text { Challenges and Opportunities of } \\
\text { HEIs towards Quality Excellence } \\
\text { as per revised manual }\end{array}$ & Sibi, K. J. (2020). [12] \\
\hline 12 & $\begin{array}{l}\text { NAAC Assessment and } \\
\text { Accreditation criteria }\end{array}$ & $\begin{array}{l}\text { Dimensions of Curricular } \\
\text { riteria }\end{array}$ & 13] \\
\hline 13 & The Role of Accreditation & $\begin{array}{l}\text { Facilitation and Regulation of } \\
\text { Educational Institutions: }\end{array}$ & $\begin{array}{l}\text { Manimala, M. J., et al. } \\
(2020) . \text { [14] }\end{array}$ \\
\hline 14 & $\begin{array}{l}\text { NAAC Assessment } \\
\text { Accreditation results }\end{array}$ & $\begin{array}{l}\text { Symbiotic Analysis of NAAC } \\
\text { Accredited Institutions }\end{array}$ & $\begin{array}{l}\text { Amutha, S., et al. } \\
(2019) .[15]\end{array}$ \\
\hline
\end{tabular}

\section{RESEARCH OBJECTIVES :}

(1) Study on Criteria wise performance of top nine A++ scored Indian Universities as per NAAC Accreditation

(2) Identification and analysis of full scores obtained in various criteria along with its type

(3) Comparison of Criteria-wise Strength and weakness of these A++ universities to determine common weakness in terms of least scored activities. 
(4) Further analysis on data on research output-based performance of the universities.

(5) Analysis of Research performance using ABC model of Research Productivity

(6) Study and analysis of role models research performance and its effect on universities

(7) Critical analysis using Organizational SWOC based on NAAC data and outcome.

\section{METHODOLOGY :}

The study uses data from the NAAC quantitative dataset, which is a repository of the scores obtained by the institutions based on expert committee assessment and validated self-study report. The data are collected from the NAAC website [1]. Further, research related data of individuals are obtained from Google scholar search pages. The research output data collected from these repositories are tabulated and analyzed using the ABC Model of annual research productivity [16-22]. The limitation of this study is that only A++ accredited universities till $31^{\text {st }}$ April 2021 as per the new Assessment policy implemented after_1st March 2018 are considered for the study.

\section{OBSERVATION \& ANALYSIS :}

\section{Output based / Performance based Accreditation system :}

For universities, as per NAAC new assessment and accreditation model adopted from July 2017 and implemented from March 2018, there are 07 Criteria, 34 Key indicators, 36 Qualitative metrics $\left(\mathrm{Q}_{1} \mathrm{M}\right)$ with $30 \%$ weightage, 79 Quantitative metrics with $70 \%$ weightage leading to 115 total metrics. As per the outcome of the self-study report evaluation and peer inspection team report, Institutional NAAC assessment Grade Sheet is prepared and the total institutional Cumulative Grade Point Average (CGPA) is calculated. This process contains calculation of GPA for individual criterion and then the calculation of cumulative grade using the procedure given below:

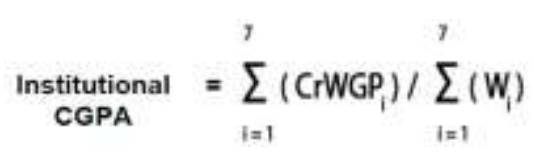

where $\mathrm{CrWGP}_{\mathrm{i}}=\sum\left(\mathrm{KIWGP}_{\mathrm{i}} / \sum \mathrm{W}_{\mathrm{i}}\right.$

Here, CrWGP is the Criteria wise weighted grade point, $\mathrm{W}$ is the Key indicator weightage, (KIWGP) is Key Indicator Wise Weighted Grade Point for individual criterion with total seven criteria and $\left(\mathrm{W}_{\mathrm{i}}\right)$ is Key Indicator Weightage for individual criteria with a total of seven criteria. Based on analysis of Overall Score out of 4.0, universities are classified into different grades as given in Table 1. While studying the grade sheets of accredited universities, it is observed that nine universities have scored more than 3.51 to be eligible under the A++ letter grade category, as are listed in table 2 along with Criteria wise Score out of 4.0 and an overall score out of 4.0.

Table 4 : Indian Universities with NAAC A++ Accreditation as of $31^{\text {st }}$ April $2021^{*}$

\begin{tabular}{|l|l|l|l|l|}
\hline RANK & University \& State & $\begin{array}{l}\text { Status and } \\
\text { Inspection year }\end{array}$ & $\begin{array}{l}\text { Criteria wise } \\
\text { Score out of } \\
\mathbf{4 . 0}\end{array}$ & $\begin{array}{l}\text { Overall Score } \\
\text { Out of 4.0 }\end{array}$ \\
\hline 1 & INDIAN INSTITUTE OF & $\begin{array}{l}\mathrm{A}++ \\
(2018)\end{array}$ & $\mathrm{C} 1-3.74$ & 3.67 \\
& SCIENCE, Bangalore, & Cycle 1 & C3 -3.84 & \\
& Karnataka. & & C4 -3.97 & \\
& & & C5 -3.38 & \\
& & & C6 -3.57 & \\
& & C7 -3.63 & \\
\hline 2 & RAMAKRISHNA MISSION & A++ & C1 -4.00 & 3.66 \\
& VIVEKANANDA & $(2019)$ & $\mathrm{C} 2-3.73$ & \\
& EDUCATIONAL AND & Cycle 1 & C3 -3.23 & \\
& RESEARCH INSTITUTE, & & $\mathrm{C} 4-3.83$ & \\
& West Bengal. & $\mathrm{C} 5-3.56$ & \\
\hline
\end{tabular}




\begin{tabular}{|c|c|c|c|c|}
\hline & & & $\begin{array}{l}\text { C6 }-3.70 \\
\text { C7 }-3.94\end{array}$ & \\
\hline 3 & $\begin{array}{l}\text { BANASTHALI VIDYAPITH } \\
\text { Banasthali, Rajasthan }\end{array}$ & $\begin{array}{l}\text { A++ } \\
(2020) \\
(\text { Cycle 3) }\end{array}$ & $\begin{array}{l}\mathrm{C} 1-3.87 \\
\mathrm{C} 2-3.47 \\
\mathrm{C} 3-3.47 \\
\mathrm{C} 4-3.62 \\
\mathrm{C} 5-3.66 \\
\mathrm{C} 6-3.60 \\
\mathrm{C} 7-3.91\end{array}$ & 3.63 \\
\hline 4 & $\begin{array}{l}\text { KONERU LAKSHMAIAH } \\
\text { EDUCATION FOUNDATION, } \\
\text { GUNTUR, } \\
\text { Andhra Pradesh. }\end{array}$ & $\begin{array}{l}\text { A++ } \\
(2018) \\
(\text { Cycle 2) }\end{array}$ & $\begin{array}{l}\mathrm{C} 1-4.00 \\
\mathrm{C} 2-3.55 \\
\mathrm{C} 3-3.41 \\
\mathrm{C} 4-3.44 \\
\mathrm{C} 5-3.19 \\
\mathrm{C} 6-3.50 \\
\mathrm{C} 7-3.93\end{array}$ & 3.57 \\
\hline 5 & $\begin{array}{l}\text { INDIRA GANDHI } \\
\text { NATIONAL OPEN } \\
\text { UNIVERSITY } \\
\text { New Delhi, Delhi. }\end{array}$ & $\begin{array}{l}\text { A++ } \\
(2021) \\
\text { Cycle 1 }\end{array}$ & $\begin{array}{l}\mathrm{C} 1-3.11 \\
\mathrm{C} 2-3.66 \\
\mathrm{C} 3-3.12 \\
\mathrm{C} 4-3.89 \\
\mathrm{C} 5-3.81 \\
\mathrm{C} 6-3.97 \\
\mathrm{C} 7-3.85 \\
\end{array}$ & 3.56 \\
\hline 6 & $\begin{array}{l}\text { SRM INSTITUTE OF } \\
\text { SCIENCE AND } \\
\text { TECHNOLOGY, } \\
\text { Chennai, Tamil Nadu. }\end{array}$ & $\begin{array}{l}\text { A++ } \\
(2018) \\
(\text { Cycle 3) }\end{array}$ & $\begin{array}{l}\mathrm{C} 1-4.00 \\
\mathrm{C} 2-3.57 \\
\mathrm{C} 3-3.45 \\
\mathrm{C} 4-3.89 \\
\mathrm{C} 5-3.39 \\
\mathrm{C} 6-2.88 \\
\mathrm{C} 7-3.57\end{array}$ & 3.55 \\
\hline 7 & $\begin{array}{l}\text { MADURAI KAMARAJ } \\
\text { UNIVERSITY, Madurai, } \\
\text { Tamil Nadu. }\end{array}$ & $\begin{array}{l}\text { A++ } \\
(2021) \\
(\text { Cycle 4) }\end{array}$ & $\begin{array}{l}\mathrm{C} 1-4.00 \\
\mathrm{C} 2-3.59 \\
\mathrm{C} 3-3.13 \\
\mathrm{C} 4-3.82 \\
\mathrm{C} 5-2.97 \\
\mathrm{C} 6-3.63 \\
\mathrm{C} 7-3.92\end{array}$ & 3.54 \\
\hline 8 & $\begin{array}{l}\text { SRI RAMACHANDRA } \\
\text { INSTITUTE OF HIGHER } \\
\text { EDUCATION AND } \\
\text { RESEARCH, Chennai, } \\
\text { Tamil Nadu. }\end{array}$ & $\begin{array}{l}\text { A++ } \\
(2021) \\
\text { (Cycle 3) }\end{array}$ & $\begin{array}{l}\mathrm{C} 1-3.63 \\
\mathrm{C} 2-3.60 \\
\mathrm{C} 3-3.38 \\
\mathrm{C} 4-3.42 \\
\mathrm{C} 5-3.48 \\
\text { C6 }-3.49 \\
\mathrm{C} 7-3.82 \\
\end{array}$ & 3.53 \\
\hline 9 & $\begin{array}{l}\text { SHIVAJI UNIVERSITY, } \\
\text { Kolhapur, } \\
\text { Maharashtra. }\end{array}$ & $\begin{array}{l}\text { A++ } \\
(2021) \\
(\text { Cycle 4) }\end{array}$ & $\begin{array}{l}\mathrm{C} 1-4.00 \\
\mathrm{C} 2-3.61 \\
\mathrm{C} 3-3.09 \\
\mathrm{C} 4-3.65 \\
\mathrm{C} 5-3.79 \\
\mathrm{C} 6-2.95 \\
\mathrm{C} 7-3.89\end{array}$ & 3.52 \\
\hline
\end{tabular}

*https://assessmentonline.naac.gov.in/public/index.php/hei_dashboard.

In table 4, ranking is given to these nine universities based on overall scores they obtained and arranged them accordingly. Indian Institute of Science, Bangalore, scored 3.67 out of 4.0 and acquired the first 
rank among nine universities that got A++ letter grade. Table 4 also gives weighted grade points scored in individual criteria of all nine universities. It is observed that some A++ graded universities scored full weighted grade points in some criterion. Table 5 separates such five A++ graded universities along with the criteria, where they scored full scores and the type of the universities. It is noticed that these five universities have scored full marks in the Curricular aspects criteria. It is also noticed that out of these five universities, three of them are private deemed universities and the other two are public state universities.

Table 5 : Full scores obtained in various Criteria along with their type

\begin{tabular}{|l|l|l|l|l|}
\hline S. No. & University Name & $\begin{array}{l}\text { Criteria where } \\
\text { full marks } \\
\text { obtained }\end{array}$ & $\begin{array}{l}\text { Criteria Score } \\
\text { out of 4.0 }\end{array}$ & $\begin{array}{l}\text { Type of } \\
\text { University }\end{array}$ \\
\hline 1 & $\begin{array}{l}\text { RAMAKRISHNA } \\
\text { MISSION } \\
\text { VIVEKANANDA } \\
\text { EDUCATIONAL AND } \\
\text { RESEARCH INSTITUTE, } \\
\text { West Bengal. }\end{array}$ & 4.0 & $\begin{array}{l}\text { Private Deemed } \\
\text { University }\end{array}$ \\
\hline 2 & $\begin{array}{l}\text { KONERU } \\
\text { LAKSHMAIAH } \\
\text { EDUCATION } \\
\text { FOUNDATION, } \\
\text { GUNTUR, } \\
\text { Andhra Pradesh. }\end{array}$ & $\begin{array}{l}\text { C1 - Curricular } \\
\text { Aspects }\end{array}$ & 4.0 & $\begin{array}{l}\text { Private Deemed } \\
\text { University }\end{array}$ \\
\hline 3 & $\begin{array}{l}\text { SRM INSTITUTE OF } \\
\text { SCIENCE AND } \\
\text { TECHNOLOGY, } \\
\text { Chennai, Tamil Nadu. }\end{array}$ & $\begin{array}{l}\text { C1: Curricular } \\
\text { Aspects }\end{array}$ & 4.0 & $\begin{array}{l}\text { Private Deemed } \\
\text { University }\end{array}$ \\
\hline 4 & $\begin{array}{l}\text { MADURAI KAMARAJ } \\
\text { UNIVERSITY, Madurai, } \\
\text { Tamil Nadu. }\end{array}$ & $\begin{array}{l}\text { C1: Curricular } \\
\text { Aspects }\end{array}$ & 4.0 & $\begin{array}{l}\text { Public State } \\
\text { University }\end{array}$ \\
\hline 5 & $\begin{array}{l}\text { SHIVAJI UNIVERSITY, } \\
\text { Kolhapur, } \\
\text { Maharashtra. }\end{array}$ & $\begin{array}{l}\text { C1: Curricular } \\
\text { Aspects }\end{array}$ & 4.0 & $\begin{array}{l}\text { Public State } \\
\text { University }\end{array}$ \\
\hline
\end{tabular}

Based on criteria wise marks scores, the criteria wise strength and weakness of these top universities are identified and listed in table 6.

Table 6: Criteria-wise Strength and weakness of A++ universities

\begin{tabular}{|c|c|c|c|}
\hline S. No. & Name of A++ University & Strength (Highest score) & Weakness (Lowest score) \\
\hline 1 & $\begin{array}{l}\text { INDIAN INSTITUTE OF } \\
\text { SCIENCE, Bangalore, } \\
\text { Karnataka. }\end{array}$ & $\begin{array}{l}\text { C2 - Teaching-learning and } \\
\text { Evaluation } \\
\text { C4 - Infrastructure and } \\
\text { Learning Resources }\end{array}$ & $\begin{array}{l}\text { C3 - Research, Innovations } \\
\text { and Extension } \\
\text { C5 - Student Support and } \\
\text { Progression }\end{array}$ \\
\hline 2 & $\begin{array}{l}\text { RAMAKRISHNA } \\
\text { MISSION } \\
\text { VIVEKANANDA } \\
\text { EDUCATIONAL AND } \\
\text { RESEARCH INSTITUTE, } \\
\text { West Bengal. }\end{array}$ & $\begin{array}{l}\text { C1 - Curricular Aspects } \\
\text { C7 - Institutional Values } \\
\text { and Best Practices }\end{array}$ & $\begin{array}{l}\text { C3 - Research, Innovations } \\
\text { and Extension } \\
\text { C5 - Student Support and } \\
\text { Progression }\end{array}$ \\
\hline 3 & $\begin{array}{l}\text { BANASTHALI } \\
\text { VIDYAPITH } \\
\text { Rajasthan. }\end{array}$ & $\begin{array}{l}\text { C1 - Curricular Aspects } \\
\text { C7 - Institutional Values } \\
\text { and Best Practices }\end{array}$ & $\begin{array}{l}\mathrm{C} 2 \text { - Teaching-learning and } \\
\text { Evaluation } \\
\mathrm{C} 3-\text { Research, Innovations } \\
\text { and Extension }\end{array}$ \\
\hline
\end{tabular}




\begin{tabular}{|c|c|c|c|}
\hline 4 & $\begin{array}{l}\text { KONERU LAKSHMAIAH } \\
\text { EDUCATION } \\
\text { FOUNDATION, } \\
\text { GUNTUR, } \\
\text { Andhra Pradesh. }\end{array}$ & $\begin{array}{l}\mathrm{C} 1-\text { Curricular Aspects } \\
\mathrm{C} 7-\text { Institutional Values } \\
\text { and Best Practices }\end{array}$ & $\begin{array}{l}\text { C3 - Research, Innovations } \\
\text { and Extension } \\
\text { C5 - Student Support and } \\
\text { Progression }\end{array}$ \\
\hline 5 & $\begin{array}{l}\text { INDIRA GANDHI } \\
\text { NATIONAL OPEN } \\
\text { UNIVERSITY } \\
\text { New Delhi, Delhi. }\end{array}$ & $\begin{array}{l}\text { C4 - Infrastructure and } \\
\text { Learning Resources } \\
\text { C6 - Governance, } \\
\text { Leadership and } \\
\text { Management }\end{array}$ & $\begin{array}{l}\text { C1 - Curricular Aspects } \\
\text { C3 - Research, Innovations } \\
\text { and Extension }\end{array}$ \\
\hline 6 & $\begin{array}{l}\text { SRM INSTITUTE OF } \\
\text { SCIENCE AND } \\
\text { TECHNOLOGY, } \\
\text { Chennai, Tamil Nadu. }\end{array}$ & $\begin{array}{l}\mathrm{C} 1 \text { - Curricular Aspects } \\
\mathrm{C} 4 \text { - Infrastructure and } \\
\text { Learning Resources }\end{array}$ & $\begin{array}{l}\text { C5 - Student Support and } \\
\text { Progression } \\
\text { C6 - Governance, } \\
\text { Leadership and Management }\end{array}$ \\
\hline 7 & $\begin{array}{l}\text { MADURAI KAMARAJ } \\
\text { UNIVERSITY, Madurai, } \\
\text { Tamil Nadu. }\end{array}$ & $\begin{array}{l}\text { C1 - Curricular Aspects } \\
\text { C7 - Institutional Values } \\
\text { and Best Practices }\end{array}$ & $\begin{array}{l}\text { C3 - Research, Innovations } \\
\text { and Extension } \\
\text { C5 - Student Support and } \\
\text { Progression }\end{array}$ \\
\hline 8 & $\begin{array}{l}\text { SRI RAMACHANDRA } \\
\text { INSTITUTE OF HIGHER } \\
\text { EDUCATION AND } \\
\text { RESEARCH, Chennai, } \\
\text { Tamil Nadu. }\end{array}$ & $\begin{array}{l}\mathrm{C} 1-\text { Curricular Aspects } \\
\mathrm{C} 7-\text { Institutional Values } \\
\text { and Best Practices }\end{array}$ & $\begin{array}{l}\text { C3 - Research, Innovations } \\
\text { and Extension } \\
\text { C4 - Infrastructure and } \\
\text { Learning Resources }\end{array}$ \\
\hline 9 & $\begin{array}{l}\text { SHIVAJI UNIVERSITY, } \\
\text { Kolhapur, } \\
\text { Maharashtra. }\end{array}$ & $\begin{array}{l}\text { C1 - Curricular Aspects } \\
\text { C7 - Institutional Values } \\
\text { and Best Practices }\end{array}$ & $\begin{array}{l}\text { C3 - Research, Innovations } \\
\text { and Extension } \\
\text { C6 - Governance, } \\
\text { Leadership and Management }\end{array}$ \\
\hline
\end{tabular}

Based on table 6, it can be understood that eight universities have obtained less scores in Research, Innovations and Extension criteria, five universities have scored less in Student Support and Progression criterion, two universities are scored less in Governance, Leadership and Management. Hence, we conducted a detailed study and analysis on the contribution of these universities for Research, Innovations and Extension criteria based activities. Table 7 lists the grade points obtained by these universities in different key indicators and the average grade points in Research, Innovations and Extension criteria. When examining the grade points scored in individual key indicators of Research, Innovations and Extension Criteria by these nine universities, some universities are scored full grade points in many key indicators. Table 8 identified such universities who have performed successfully and made full scores in one or more key indicator activities in Research, Innovations and Extension Criterion. Accordingly, Indian Institute of Science, Bangalore and SRM Institute of Science and Technology, Chennai, have obtained full score points in five out of seven criteria. Ramakrishna Mission Vivekananda Educational and Research Institute, Banasthali Vidyapith, and Madurai Kamaraj University have obtained full score points in four out of seven criteria. Koneru Lakshmaiah Education Foundation, and Indira Gandhi National Open University have obtained full score points in three out of seven criteria. Ranks are also allotted for universities based on their average grade points in criteria 3, i.e., in criteria Research, Innovations and Extension (table 7).

Table 7 : Grade points earned in Research, Innovations and Extension Criteria by A++ graded universities

\begin{tabular}{|l|l|l|l|l|}
\hline $\begin{array}{l}\text { S. } \\
\text { No. }\end{array}$ & University \& State & $\begin{array}{l}\text { Key Indicators and Grade points out of } \\
\mathbf{4 . 0}\end{array}$ & $\begin{array}{l}\text { Grade } \\
\text { points } \\
\text { Average in } \\
\text { Criteria 3 }\end{array}$ & $\begin{array}{l}\text { Rank in } \\
\text { Criteria 3 }\end{array}$ \\
\hline 1 & $\begin{array}{l}\text { INDIAN } \\
\text { INSTITUTE OF }\end{array}$ & $\begin{array}{l}\text { Promotion of Research and Facilities - } \\
4.0\end{array}$ & & \\
\hline
\end{tabular}




\begin{tabular}{|c|c|c|c|c|}
\hline & $\begin{array}{l}\text { SCIENCE, } \\
\text { Bangalore, } \\
\text { Karnataka. }\end{array}$ & $\begin{array}{l}\text { Resource Mobilization for Research - } \\
4.0 \\
\text { Innovation Ecosystem - } 4.0 \\
\text { Research Publications and Awards - } \\
3.66 \\
\text { Consultancy }-4.0 \\
\text { Extension Activities }-2.0 \\
\text { Collaboration }-4.0\end{array}$ & 3.54 & $\begin{array}{l}\text { First } \\
\text { Rank }\end{array}$ \\
\hline 2 & $\begin{array}{l}\text { RAMAKRISHNA } \\
\text { MISSION } \\
\text { VIVEKANANDA } \\
\text { EDUCATIONAL } \\
\text { AND RESEARCH } \\
\text { INSTITUTE, } \\
\text { West Bengal. }\end{array}$ & $\begin{array}{l}\text { Promotion of Research and Facilities - } \\
4.0 \\
\text { Resource Mobilization for Research - } \\
2.95 \\
\text { Innovation Ecosystem - } 3.7 \\
\text { Research Publications and Awards - } \\
2.48 \\
\text { Consultancy - } 4.0 \\
\text { Extension Activities }-4.0 \\
\text { Collaboration }-4.0\end{array}$ & 3.23 & $\begin{array}{l}\text { Sixth } \\
\text { Rank }\end{array}$ \\
\hline 3 & $\begin{array}{l}\text { BANASTHALI } \\
\text { VIDYAPITH } \\
\text { Rajasthan, } \\
\text { Banasthali } \\
\text { Vidyapith, 304022, } \\
\text { P.O. Banasthali } \\
\text { Vidyapith, Dist. } \\
\text { Tonk, Rajasthan }\end{array}$ & $\begin{array}{l}\text { Promotion of Research and Facilities - } \\
3.3 \\
\text { Resource Mobilization for Research - } \\
\text { 3.75 } \\
\text { Innovation Ecosystem - } 4.0 \\
\text { Research Publications and Awards - } \\
2.95 \\
\text { Consultancy - } 4.0 \\
\text { Extension Activities }-4.0 \\
\text { Collaboration }-4.0\end{array}$ & 3.47 & $\begin{array}{l}\text { Second } \\
\text { Rank }\end{array}$ \\
\hline 4 & $\begin{array}{l}\text { KONERU } \\
\text { LAKSHMAIAH } \\
\text { EDUCATION } \\
\text { FOUNDATION, } \\
\text { GUNTUR, } \\
\text { Andhra Pradesh. }\end{array}$ & $\begin{array}{l}\text { Promotion of Research and Facilities - } \\
\text { 3.1 } \\
\text { Resource Mobilization for Research - } \\
\text { 3.7 } \\
\text { Innovation Ecosystem - } 4.0 \\
\text { Research Publications and Awards - } \\
2.67 \\
\text { Consultancy }-4.0 \\
\text { Extension Activities - } 4.0 \\
\text { Collaboration }-3.75\end{array}$ & 3.41 & $\begin{array}{l}\text { Fourth } \\
\text { Rank }\end{array}$ \\
\hline 5 & $\begin{array}{l}\text { INDIRA GANDHI } \\
\text { NATIONAL OPEN } \\
\text { UNIVERSITY } \\
\text { New Delhi, Delhi. }\end{array}$ & $\begin{array}{l}\text { Promotion of Research and Facilities - } \\
4.0 \\
\text { Resource Mobilization for Research - } \\
1.33 \\
\text { Innovation Ecosystem }-4.0 \\
\text { Research Publications and Awards - } \\
2.69 \\
\text { Consultancy - } 1.8 \\
\text { Extension Activities }-3.43 \\
\text { Collaboration }-4.0\end{array}$ & 3.12 & $\begin{array}{l}\text { Eight } \\
\text { Rank }\end{array}$ \\
\hline 6 & $\begin{array}{l}\text { SRM INSTITUTE } \\
\text { OF SCIENCE AND } \\
\text { TECHNOLOGY, } \\
\text { Chennai, Tamil } \\
\text { Nadu. }\end{array}$ & $\begin{array}{l}\text { Promotion of Research and Facilities - } \\
4.0 \\
\text { Resource Mobilization for Research - } \\
\text { 3.0 } \\
\text { Innovation Ecosystem - } 4.0 \\
\text { Research Publications and Awards - } \\
2.71\end{array}$ & 3.45 & $\begin{array}{l}\text { Third } \\
\text { Rank }\end{array}$ \\
\hline
\end{tabular}




\begin{tabular}{|c|c|c|c|c|}
\hline & & $\begin{array}{l}\text { Consultancy }-4.0 \\
\text { Extension Activities }-4.0 \\
\text { Collaboration }-4.0\end{array}$ & & \\
\hline 7 & $\begin{array}{l}\text { MADURAI } \\
\text { KAMARAJ } \\
\text { UNIVERSITY, } \\
\text { Madurai, } \\
\text { Tamil Nadu. }\end{array}$ & $\begin{array}{l}\text { Promotion of Research and Facilities - } \\
1.9 \\
\text { Resource Mobilization for Research - } \\
4.0 \\
\text { Innovation Ecosystem }-4.0 \\
\text { Research Publications and Awards - } \\
3.31 \\
\text { Consultancy }-4.0 \\
\text { Extension Activities }-1.75 \\
\text { Collaboration }-4.0\end{array}$ & 3.13 & $\begin{array}{l}\text { Seventh } \\
\text { Rank }\end{array}$ \\
\hline 8 & $\begin{array}{l}\text { SRI } \\
\text { RAMACHANDRA } \\
\text { INSTITUTE OF } \\
\text { HIGHER } \\
\text { EDUCATION AND } \\
\text { RESEARCH, } \\
\text { Chennai, } \\
\text { Tamil Nadu. }\end{array}$ & $\begin{array}{l}\text { Promotion of Research and Facilities - } \\
\text { 3.9 } \\
\text { Resource Mobilization for Research - } \\
\text { 4.0 } \\
\text { Innovation Ecosystem - } 3.45 \\
\text { Research Publications and Awards - } \\
\text { 3.09 } \\
\text { Consultancy - 3.33 } \\
\text { Extension Activities - } 3.56 \\
\text { Collaboration }-3.0\end{array}$ & 3.38 & $\begin{array}{l}\text { Fifth } \\
\text { Rank }\end{array}$ \\
\hline 9 & $\begin{array}{l}\text { SHIVAJI } \\
\text { UNIVERSITY, } \\
\text { Kolhapur, } \\
\text { Maharashtra. }\end{array}$ & $\begin{array}{l}\text { Promotion of Research and Facilities - } \\
1.88 \\
\text { Resource Mobilization for Research - } \\
3.7 \\
\text { Innovation Ecosystem - } 2.67 \\
\text { Research Publications and Awards - } \\
2.93 \\
\text { Consultancy - } 4.0 \\
\text { Extension Activities }-3.25 \\
\text { Collaboration }-4.0\end{array}$ & 3.09 & $\begin{array}{l}\text { Ninth } \\
\text { Rank }\end{array}$ \\
\hline
\end{tabular}

Our calculation is based on datasets downloaded from NAAC

https://assessmentonline.naac.gov.in/public/index.php/hei_dashboard

Table 8: Full scored key indicator activities in Research, Innovations and Extension Criterion

\begin{tabular}{|c|c|c|c|}
\hline $\begin{array}{l}\text { S. } \\
\text { No. }\end{array}$ & University \& State & $\begin{array}{l}\text { Key Indicators and Grade points out of } \\
4.0 *\end{array}$ & $\begin{array}{l}\text { Number of Key } \\
\text { Indicators out } \\
\text { of } 7\end{array}$ \\
\hline 1 & $\begin{array}{l}\text { INDIAN INSTITUTE OF } \\
\text { SCIENCE, Bangalore, } \\
\text { Karnataka. }\end{array}$ & $\begin{array}{l}\text { Promotion of Research and Facilities }- \\
4.0 \\
\text { Resource Mobilization for Research }-4.0 \\
\text { Innovation Ecosystem }-4.0 \\
\text { Consultancy }-4.0 \\
\text { Collaboration }-4.0\end{array}$ & 5 \\
\hline 2 & $\begin{array}{l}\text { RAMAKRISHNA } \\
\text { MISSION } \\
\text { VIVEKANANDA } \\
\text { EDUCATIONAL AND } \\
\text { RESEARCH INSTITUTE, } \\
\text { West Bengal. }\end{array}$ & $\begin{array}{l}\text { Promotion of Research and Facilities }-4.0 \\
\text { Consultancy }-4.0 \\
\text { Extension Activities }-4.0 \\
\text { Collaboration }-4.0\end{array}$ & 4 \\
\hline 3 & $\begin{array}{l}\text { BANASTHALI } \\
\text { VIDYAPITH }\end{array}$ & $\begin{array}{l}\text { Innovation Ecosystem }-4.0 \\
\text { Consultancy }-4.0\end{array}$ & 4 \\
\hline
\end{tabular}




\begin{tabular}{|c|c|c|c|}
\hline & Rajasthan, & $\begin{array}{l}\text { Extension Activities }-4.0 \\
\text { Collaboration }-4.0\end{array}$ & \\
\hline 4 & $\begin{array}{l}\text { KONERU LAKSHMAIAH } \\
\text { EDUCATION } \\
\text { FOUNDATION, } \\
\text { GUNTUR, } \\
\text { Andhra Pradesh. } \\
\end{array}$ & $\begin{array}{l}\text { Innovation Ecosystem }-4.0 \\
\text { Consultancy }-4.0 \\
\text { Extension Activities }-4.0\end{array}$ & 3 \\
\hline 5 & $\begin{array}{l}\text { INDIRA GANDHI } \\
\text { NATIONAL OPEN } \\
\text { UNIVERSITY } \\
\text { New Delhi, Delhi. } \\
\end{array}$ & $\begin{array}{l}\text { Promotion of Research and Facilities - } \\
4.0 \\
\text { Innovation Ecosystem }-4.0 \\
\text { Collaboration }-4.0\end{array}$ & 3 \\
\hline 6 & $\begin{array}{l}\text { SRM INSTITUTE OF } \\
\text { SCIENCE AND } \\
\text { TECHNOLOGY, } \\
\text { Chennai, Tamil Nadu. }\end{array}$ & $\begin{array}{l}\text { Promotion of Research and Facilities - } \\
4.0 \\
\text { Innovation Ecosystem }-4.0 \\
\text { Consultancy }-4.0 \\
\text { Extension Activities }-4.0 \\
\text { Collaboration }-4.0\end{array}$ & 5 \\
\hline 7 & $\begin{array}{l}\text { MADURAI KAMARAJ } \\
\text { UNIVERSITY, Madurai, } \\
\text { Tamil Nadu. }\end{array}$ & $\begin{array}{l}\text { Resource Mobilization for Research }-4.0 \\
\text { Innovation Ecosystem }-4.0 \\
\text { Consultancy }-4.0 \\
\text { Collaboration }-4.0\end{array}$ & 4 \\
\hline 8 & $\begin{array}{l}\text { SRI RAMACHANDRA } \\
\text { INSTITUTE OF HIGHER } \\
\text { EDUCATION AND } \\
\text { RESEARCH, Chennai, } \\
\text { Tamil Nadu. }\end{array}$ & Resource Mobilization for Research -4.0 & 1 \\
\hline 9 & $\begin{array}{l}\text { SHIVAJI UNIVERSITY, } \\
\text { Kolhapur, } \\
\text { Maharashtra. }\end{array}$ & $\begin{array}{l}\text { Consultancy }-4.0 \\
\text { Collaboration }-4.0\end{array}$ & 2 \\
\hline
\end{tabular}

Based on analysis of table 8 , it is found that out of nine A++ universities, two universities are scored full marks in five activities (key indicators) out of seven activities, three universities are scored full marks in four activities, two universities have scored full marks in three activities, one university has scored full marks in two activities, and one university has scored full marks in one activity.

Table 9 : Least scored activities in Research, Innovations and Extension Criterion

\begin{tabular}{|c|c|c|c|}
\hline $\begin{array}{l}\text { S. } \\
\text { No. }\end{array}$ & University \& State & $\begin{array}{l}\text { Key Indicators and Grade points out of } \\
4.0 *\end{array}$ & Grade points \\
\hline \multirow[t]{2}{*}{1} & \multirow{2}{*}{$\begin{array}{l}\text { INDIAN INSTITUTE OF } \\
\text { SCIENCE, Bangalore, } \\
\text { Karnataka. }\end{array}$} & Research Publications and Awards & 3.66 \\
\hline & & Extension Activities & 2.00 \\
\hline \multirow[t]{3}{*}{2} & \multirow{3}{*}{$\begin{array}{l}\text { RAMAKRISHNA } \\
\text { MISSION } \\
\text { VIVEKANANDA } \\
\text { EDUCATIONAL AND } \\
\text { RESEARCH } \\
\text { INSTITUTE, } \\
\text { West Bengal. }\end{array}$} & Resource Mobilization for Research & 2.95 \\
\hline & & & \\
\hline & & Research Publications and Awards & 2.48 \\
\hline \multirow[t]{2}{*}{3} & \multirow{2}{*}{$\begin{array}{l}\text { BANASTHALI } \\
\text { VIDYAPITH } \\
\text { Rajasthan, Rajasthan }\end{array}$} & Promotion of Research and Facilities & 3.30 \\
\hline & & Research Publications and Awards & 2.95 \\
\hline
\end{tabular}




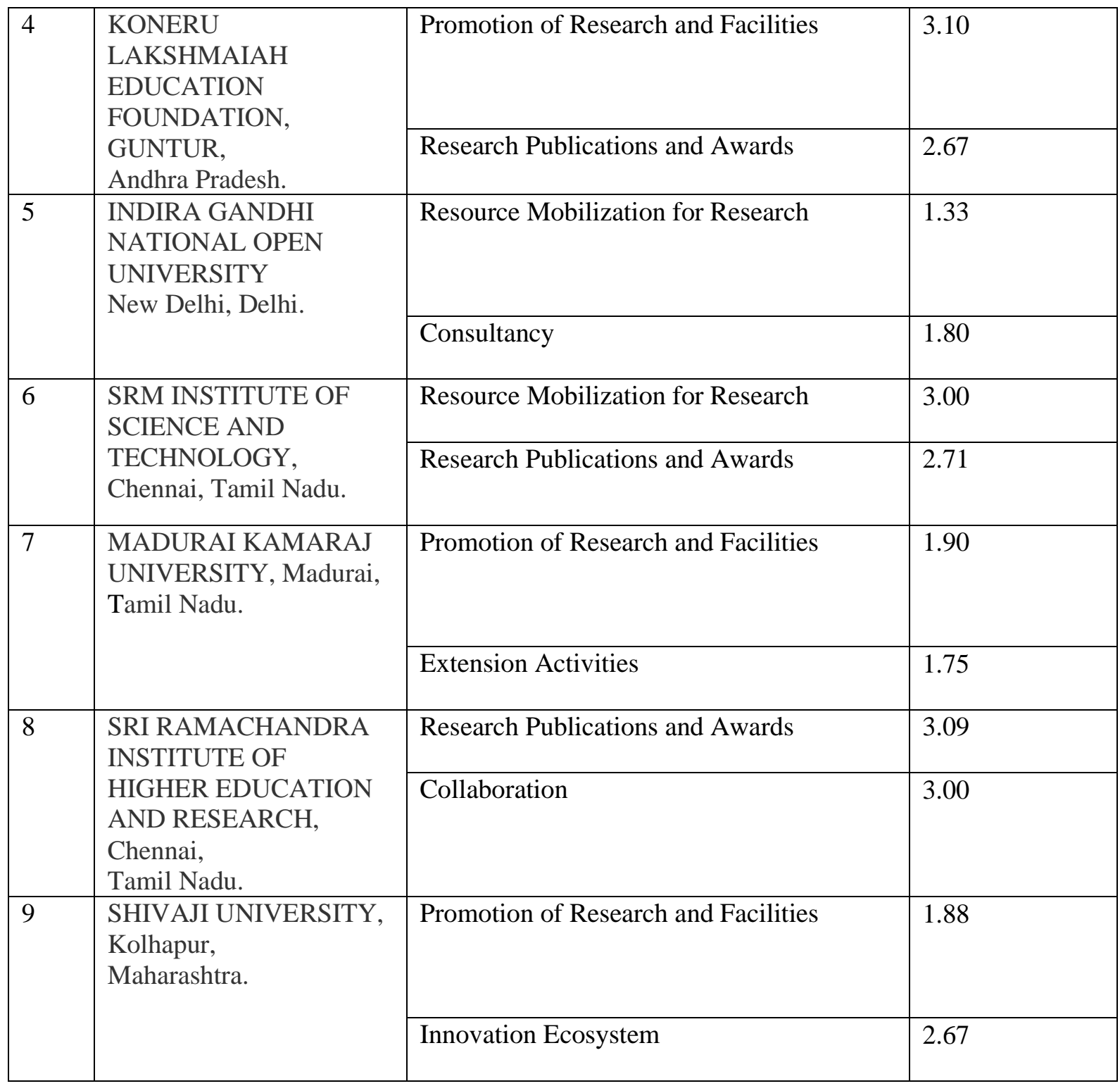

Based on table 9, it is found that out of nine A++ universities, six universities are scored least grade points in the key indicator activity Research Publications and Awards. Except Indian Institute of Science, Bangalore, other universities could not retain 3.5 grade points out of 4.0 grade points. Many of A++ grade universities have scored less than 3.0 grade points in this Research Publications and Awards Key indicator component. Hence it is decided to study and analyse the details of Research Publications key indicator activity further, for all nine universities by referring to their Self-Study Report (SSR) from the dataset provided by National Assessment and Accreditation Council website.

\section{DETAILED STUDY AND ANALYSIS OF NINE A++ UNIVERSITIES USING SELF-STUDY REPORT :}

In this section, a detailed study on issues related to research publication is carried out by refereeing selfstudy reports of individual universities and the annual research index and average research index for a period of last five years of these universities are calculated and compared as per $\mathrm{ABC}$ model of research productivity [16-22]. ABC model of organizational research productivity focuses on research output of an organization. Based on individual and team of faculty members performance, the research productivity is measured only on research publication in the form of articles published in scholarly journals (A), Books (edited) published (B), and Chapters, Conference papers, Case studies, \& Patents published (C) with different weightage given to each category. ABC model of research productivity can 
be used for determining individuals annual research contribution as well as organizational research contribution for a fixed time duration.

\subsection{Faculty - Student ratio in the A++ graded Universities :}

The average number of faculty members during last five years and the student-faculty ratio of these nine A++ universities are collected from respective self-study reports and listed in table 10. It is noticed that Ramakrishna Mission Vivekananda Educational and Research Institute had the least student faculty ratio (8.22) followed by the Indian Institute of Science, Bangalore (9.60). Shivaji University, Kolhapur, had the highest ratio (40.0), and being open university Indira Gandhi National Open University had student - faculty ratio $(1,996)$ and proved as most economical university.

Table 10: Student faculty ratio of A++ universities as per their institutional SSR reports

\begin{tabular}{|c|c|c|c|c|c|}
\hline S. No. & University \& State & Year of Est. & $\begin{array}{l}\text { No. of } \\
\text { Teaching } \\
\text { Faculty } \\
\text { members }\end{array}$ & $\begin{array}{l}\text { No. of } \\
\text { Students }\end{array}$ & $\begin{array}{l}\text { Student : } \\
\text { Faculty } \\
\text { Ratio }\end{array}$ \\
\hline 1 & $\begin{array}{l}\text { INDIAN INSTITUTE } \\
\text { OF SCIENCE, } \\
\text { Bangalore, } \\
\text { Karnataka. }\end{array}$ & 1909 & 430 & 4,128 & 9.60 \\
\hline 2 & $\begin{array}{l}\text { RAMAKRISHNA } \\
\text { MISSION } \\
\text { VIVEKANANDA } \\
\text { EDUCATIONAL AND } \\
\text { RESEARCH } \\
\text { INSTITUTE, } \\
\text { West Bengal. }\end{array}$ & 2005 & 114 & 937 & 8.22 \\
\hline 3 & $\begin{array}{l}\text { BANASTHALI } \\
\text { VIDYAPITH } \\
\text { Rajasthan, }\end{array}$ & 1983 & 537 & 11,697 & 22.0 \\
\hline 4 & $\begin{array}{l}\text { KONERU } \\
\text { LAKSHMAIAH } \\
\text { EDUCATION } \\
\text { FOUNDATION, } \\
\text { GUNTUR, } \\
\text { Andhra Pradesh. }\end{array}$ & 2009 & 1,180 & 15,020 & 12.8 \\
\hline 5 & $\begin{array}{l}\text { INDIRA GANDHI } \\
\text { NATIONAL OPEN } \\
\text { UNIVERSITY } \\
\text { New Delhi, Delhi. }\end{array}$ & 1985 & 498 & $9,94,044$ & 1996 \\
\hline 6 & $\begin{array}{l}\text { SRM INSTITUTE OF } \\
\text { SCIENCE AND } \\
\text { TECHNOLOGY, } \\
\text { Chennai, Tamil Nadu. }\end{array}$ & 2002 & 3,287 & 51,841 & 16.0 \\
\hline 7 & $\begin{array}{l}\text { MADURAI } \\
\text { KAMARAJ } \\
\text { UNIVERSITY, } \\
\text { Madurai, } \\
\text { Tamil Nadu. } \\
\end{array}$ & 1965 & 182 & 2,788 & 15.3 \\
\hline 8 & $\begin{array}{l}\text { SRI } \\
\text { RAMACHANDRA } \\
\text { INSTITUTE OF } \\
\text { HIGHER } \\
\text { EDUCATION AND }\end{array}$ & 1994 & 729 & 7,188 & 10.0 \\
\hline
\end{tabular}




\begin{tabular}{|l|l|l|l|l|l|}
\hline & $\begin{array}{l}\text { RESEARCH, Chennai, } \\
\text { Tamil Nadu. }\end{array}$ & & & & \\
\hline 9 & $\begin{array}{l}\text { SHIVAJI } \\
\text { UNIVERSITY, } \\
\text { Kolhapur, } \\
\text { Maharashtra. }\end{array}$ & 1962 & 180 & 7,147 & 40.0 \\
\hline
\end{tabular}

7.2 Number of Faculty members having Ph.D. and higher research degrees:

Table 11 lists the number and ratio of faculty members having Ph.D. research degree. Indian Institute of Science, Bangalore has registered 100\% faculty members with Ph.D. degree, however, SRM Institute of Science and Technology, Chennai, and Koneru Lakshmaiah Education Foundation have registered least number of Ph.D. qualified faculty members as $32 \%$ and $27.6 \%$ respectively.

Table 11: Number of Faculty members having Ph.D. and higher research degrees

\begin{tabular}{|c|c|c|c|c|}
\hline S. No. & University & $\begin{array}{l}\text { No. of Teaching } \\
\text { Faculty members } \\
\text { having Ph.D. }\end{array}$ & $\begin{array}{l}\text { No. of Faculty } \\
\text { members }\end{array}$ & Ph.D. Ratio \\
\hline 1 & $\begin{array}{l}\text { INDIAN INSTITUTE OF } \\
\text { SCIENCE, Bangalore, } \\
\text { Karnataka. }\end{array}$ & 430 & 430 & $100 \%$ \\
\hline 2 & $\begin{array}{l}\text { RAMAKRISHNA MISSION } \\
\text { VIVEKANANDA } \\
\text { EDUCATIONAL AND } \\
\text { RESEARCH INSTITUTE, } \\
\text { West Bengal. }\end{array}$ & 93 & 114 & $81.6 \%$ \\
\hline 3 & $\begin{array}{l}\text { BANASTHALI VIDYAPITH } \\
\text { Rajasthan, Banasthali Vidyapith, } \\
\text { 304022, P.O. Banasthali } \\
\text { Vidyapith, Dist. Tonk, } \\
\text { Rajasthan }\end{array}$ & 389 & 537 & $72.4 \%$ \\
\hline 4 & $\begin{array}{l}\text { KONERU LAKSHMAIAH } \\
\text { EDUCATION FOUNDATION, } \\
\text { GUNTUR, } \\
\text { Andhra Pradesh. }\end{array}$ & 326 & 1,180 & $27.6 \%$ \\
\hline 5 & $\begin{array}{l}\text { INDIRA GANDHI NATIONAL } \\
\text { OPEN UNIVERSITY } \\
\text { New Delhi, Delhi. }\end{array}$ & 437 & 498 & $88 \%$ \\
\hline 6 & $\begin{array}{l}\text { SRM INSTITUTE OF } \\
\text { SCIENCE AND } \\
\text { TECHNOLOGY, } \\
\text { Chennai, Tamil Nadu. }\end{array}$ & 1,045 & 3,287 & $32 \%$ \\
\hline 7 & $\begin{array}{l}\text { MADURAI KAMARAJ } \\
\text { UNIVERSITY, Madurai, } \\
\text { Tamil Nadu. }\end{array}$ & 174 & 182 & $95 \%$ \\
\hline 8 & $\begin{array}{l}\text { SRI RAMACHANDRA } \\
\text { INSTITUTE OF HIGHER } \\
\text { EDUCATION AND } \\
\text { RESEARCH, Chennai, } \\
\text { Tamil Nadu. }\end{array}$ & 558 & 729 & $77 \%$ \\
\hline 9 & $\begin{array}{l}\text { SHIVAJI UNIVERSITY, } \\
\text { Kolhapur, } \\
\text { Maharashtra. }\end{array}$ & 163 & 201 & $81 \%$ \\
\hline
\end{tabular}


7.3 Number of Research papers published per faculty during last 5 years

The number of scholarly research papers published during last five years and the average number of papers published per faculty per year is calculated based on the data provided in institutional self-study reports and are listed in table 12. Indian Institute of Science, Bangalore has published highest number of journal papers with annual faculty journal research productivity 4.23. Sri Ramachandra Institute of Higher Education and Research, Chennai, Banasthali Vidyapith, Rajasthan, and SRM Institute of Science and Technology, Chennai, have published least number of journal papers with annual faculty journal research productivity less than one.

Table 12: Average number of research papers published per faculty per year

\begin{tabular}{|c|c|c|c|c|c|}
\hline S. No. & University \& State & $\begin{array}{l}\text { No. of } \\
\text { Teaching } \\
\text { Faculty } \\
\text { members }\end{array}$ & $\begin{array}{l}\text { No. of } \\
\text { students } \\
\text { doing Ph.D. } \\
\text { \& PDFs }\end{array}$ & $\begin{array}{l}\text { No. of } \\
\text { Research } \\
\text { Papers } \\
\text { Published } \\
\text { during last } 5 \\
\text { years }\end{array}$ & $\begin{array}{l}\text { Average } \\
\text { number of } \\
\text { publications } \\
\text { per faculty } \\
\text { per year }\end{array}$ \\
\hline 1 & $\begin{array}{l}\text { INDIAN INSTITUTE OF } \\
\text { SCIENCE, Bangalore, } \\
\text { Karnataka. }\end{array}$ & 430 & 700 & 8,779 & 4.23 \\
\hline 2 & $\begin{array}{l}\text { RAMAKRISHNA } \\
\text { MISSION } \\
\text { VIVEKANANDA } \\
\text { EDUCATIONAL AND } \\
\text { RESEARCH } \\
\text { INSTITUTE, } \\
\text { West Bengal. } \\
\end{array}$ & 93 & 54 & 646 & 1.57 \\
\hline 3 & $\begin{array}{l}\text { BANASTHALI } \\
\text { VIDYAPITH } \\
\text { Rajasthan, Banasthali } \\
\text { Vidyapith, 304022, P.O. } \\
\text { Banasthali Vidyapith, } \\
\text { Dist. Tonk, Rajasthan }\end{array}$ & 389 & 270 & 2,045 & 0.93 \\
\hline 4 & $\begin{array}{l}\text { KONERU } \\
\text { LAKSHMAIAH } \\
\text { EDUCATION } \\
\text { FOUNDATION, } \\
\text { GUNTUR, } \\
\text { Andhra Pradesh. }\end{array}$ & 1,180 & 243 & 4,694 & 1.25 \\
\hline 5 & $\begin{array}{l}\text { INDIRA GANDHI } \\
\text { NATIONAL OPEN } \\
\text { UNIVERSITY } \\
\text { New Delhi, Delhi. }\end{array}$ & 498 & 32 & 1,138 & 2.18 \\
\hline 6 & $\begin{array}{l}\text { SRM INSTITUTE OF } \\
\text { SCIENCE AND } \\
\text { TECHNOLOGY, } \\
\text { Chennai, Tamil Nadu. }\end{array}$ & 3,287 & 1,087 & 10,023 & 0.82 \\
\hline 7 & $\begin{array}{l}\text { MADURAI KAMARAJ } \\
\text { UNIVERSITY, Madurai, } \\
\text { Tamil Nadu. }\end{array}$ & 182 & 1,382 & 1,631 & 1.6 \\
\hline 8 & $\begin{array}{l}\text { SRI RAMACHANDRA } \\
\text { INSTITUTE OF HIGHER } \\
\text { EDUCATION AND } \\
\text { RESEARCH, Chennai, } \\
\text { Tamil Nadu. }\end{array}$ & 729 & 81 & 2,312 & 0.98 \\
\hline
\end{tabular}




\begin{tabular}{|l|l|l|l|l|l|}
\hline 9 & $\begin{array}{l}\text { SHIVAJI UNIVERSITY, } \\
\text { Kolhapur, } \\
\text { Maharashtra. }\end{array}$ & 201 & 394 & 2,689 & 1.88 \\
\hline
\end{tabular}

Table 13 lists the average number of Books, Chapters and Conference papers published per faculty per year by NAAC A++ graded universities. Again, Indian Institute of Science, Bangalore has contributed highest with more than one article per faculty per year, whereas Sri Ramachandra Institute of Higher Education and Research, Chennai, contributed least with 0.05 articles/books per faculty members per year.

Table 13: Books and other scholarly articles Publication per faculty per year

\begin{tabular}{|c|c|c|c|c|}
\hline S. No. & University \& State & $\begin{array}{l}\text { No. of } \\
\text { Teaching } \\
\text { Faculty } \\
\text { members }\end{array}$ & $\begin{array}{l}\text { No. of Books, } \\
\text { Chapters \& } \\
\text { Conference } \\
\text { papers } \\
\text { Published } \\
\text { during last } 5 \\
\text { years }\end{array}$ & $\begin{array}{l}\text { No. of Books, } \\
\text { Chapters \& } \\
\text { Conference } \\
\text { papers } \\
\text { Published per } \\
\text { faculty per year }\end{array}$ \\
\hline 1 & $\begin{array}{l}\text { INDIAN INSTITUTE OF } \\
\text { SCIENCE, Bangalore, } \\
\text { Karnataka. }\end{array}$ & 430 & 2,954 & 1.43 \\
\hline 2 & $\begin{array}{l}\text { RAMAKRISHNA MISSION } \\
\text { VIVEKANANDA } \\
\text { EDUCATIONAL AND } \\
\text { RESEARCH INSTITUTE, } \\
\text { West Bengal. }\end{array}$ & 93 & 253 & 0.62 \\
\hline 3 & $\begin{array}{l}\text { BANASTHALI VIDYAPITH } \\
\text { Rajasthan }\end{array}$ & 389 & 569 & 0.29 \\
\hline 4 & $\begin{array}{l}\text { KONERU LAKSHMAIAH } \\
\text { EDUCATION } \\
\text { FOUNDATION, GUNTUR, } \\
\text { Andhra Pradesh. }\end{array}$ & 1,180 & 4,599 & 0.78 \\
\hline 5 & $\begin{array}{l}\text { INDIRA GANDHI } \\
\text { NATIONAL OPEN } \\
\text { UNIVERSITY } \\
\text { New Delhi, Delhi. } \\
\end{array}$ & 498 & 655 & 0.26 \\
\hline 6 & $\begin{array}{l}\text { SRM INSTITUTE OF } \\
\text { SCIENCE AND } \\
\text { TECHNOLOGY, } \\
\text { Chennai, Tamil Nadu. }\end{array}$ & 3,287 & 3,023 & 0.26 \\
\hline 7 & $\begin{array}{l}\text { MADURAI KAMARAJ } \\
\text { UNIVERSITY, Madurai, } \\
\text { Tamil Nadu. }\end{array}$ & 182 & 1,409 & 1.37 \\
\hline 8 & $\begin{array}{l}\text { SRI RAMACHANDRA } \\
\text { INSTITUTE OF HIGHER } \\
\text { EDUCATION AND } \\
\text { RESEARCH, Chennai, } \\
\text { Tamil Nadu. } \\
\end{array}$ & 729 & 182 & 0.05 \\
\hline 9 & $\begin{array}{l}\text { SHIVAJI UNIVERSITY, } \\
\text { Kolhapur, } \\
\text { Maharashtra. }\end{array}$ & 201 & 841 & 0.59 \\
\hline
\end{tabular}

\subsection{Quality of Research Output :}

The quality of research output of these universities, in general, can be estimated by their average number of citations and patents per faculty per year. Table 14 lists the average number of citations registered 
per faculty per year and the institutional H-Index. Table 15 lists number of patents registered per faculty per year. Being a research university, Indian Institute of Science, Bangalore has contributed maximum to number of citations per faculty per year (35) and scored maximum institutional H-index (76). Ramakrishna Mission Vivekananda Educational and Research Institute, West Bengal has contributed least to number of citations per faculty per year (0.71) and scored institutional H-index as 12.5. All A++ graded universities have not given importance to patents as it comes under industrial research category.

Table 14: Number of Citations per faculty per year

\begin{tabular}{|c|c|c|c|c|c|}
\hline S. No. & University \& State & $\begin{array}{l}\text { No. of } \\
\text { Teaching } \\
\text { Faculty } \\
\text { members }\end{array}$ & $\begin{array}{l}\text { No. of } \\
\text { Citations } \\
\text { during last } 5 \\
\text { years }\end{array}$ & $\begin{array}{l}\text { No. of } \\
\text { Citations } \\
\text { per faculty } \\
\text { per year }\end{array}$ & $\begin{array}{l}\text { H-Index of } \\
\text { University }\end{array}$ \\
\hline 1 & $\begin{array}{l}\text { INDIAN INSTITUTE OF } \\
\text { SCIENCE, Bangalore, } \\
\text { Karnataka. }\end{array}$ & 430 & 75,750 & 35 & 76 \\
\hline 2 & $\begin{array}{l}\text { RAMAKRISHNA } \\
\text { MISSION } \\
\text { VIVEKANANDA } \\
\text { EDUCATIONAL AND } \\
\text { RESEARCH INSTITUTE, } \\
\text { West Bengal. } \\
\end{array}$ & 93 & 330 & 0.71 & 12.5 \\
\hline 3 & $\begin{array}{l}\text { BANASTHALI } \\
\text { VIDYAPITH } \\
\text { Rajasthan }\end{array}$ & 389 & 2,151 & 1.106 & 40.5 \\
\hline 4 & $\begin{array}{l}\text { KONERU LAKSHMAIAH } \\
\text { EDUCATION } \\
\text { FOUNDATION, } \\
\text { GUNTUR, } \\
\text { Andhra Pradesh. }\end{array}$ & 1,180 & 4,431 & 0.75 & 25 \\
\hline 5 & $\begin{array}{l}\text { INDIRA GANDHI } \\
\text { NATIONAL OPEN } \\
\text { UNIVERSITY } \\
\text { New Delhi, Delhi. }\end{array}$ & 498 & 2,315 & 0.93 & 21.5 \\
\hline 6 & $\begin{array}{l}\text { SRM INSTITUTE OF } \\
\text { SCIENCE AND } \\
\text { TECHNOLOGY, } \\
\text { Chennai, Tamil Nadu. }\end{array}$ & 3,287 & 21,779 & 1.33 & 42 \\
\hline 7 & $\begin{array}{l}\text { MADURAI KAMARAJ } \\
\text { UNIVERSITY, Madurai, } \\
\text { Tamil Nadu. }\end{array}$ & 182 & 1,324 & 1.46 & 38.5 \\
\hline 8 & $\begin{array}{l}\text { SRI RAMACHANDRA } \\
\text { INSTITUTE OF HIGHER } \\
\text { EDUCATION AND } \\
\text { RESEARCH, Chennai, } \\
\text { Tamil Nadu. }\end{array}$ & 729 & 17,132 & 4.7 & 40.5 \\
\hline 9 & $\begin{array}{l}\text { SHIVAJI UNIVERSITY, } \\
\text { Kolhapur, } \\
\text { Maharashtra. }\end{array}$ & 201 & 1,497 & 1.49 & 41 \\
\hline
\end{tabular}

Table 15: Number of Patents per faculty per year

\begin{tabular}{|l|l|l|l|l|}
\hline S. No. & University \& State & $\begin{array}{l}\text { No. of Teaching } \\
\text { Faculty } \\
\text { members }\end{array}$ & $\begin{array}{l}\text { No. of Patents } \\
\text { during last } 5 \\
\text { years }\end{array}$ & $\begin{array}{l}\text { No. of Patents per } \\
\text { faculty per year }\end{array}$ \\
\hline
\end{tabular}




\begin{tabular}{|c|c|c|c|c|}
\hline 1 & $\begin{array}{l}\text { INDIAN INSTITUTE OF } \\
\text { SCIENCE, Bangalore, } \\
\text { Karnataka. }\end{array}$ & 430 & 258 & 0.1200 \\
\hline 2 & $\begin{array}{l}\text { RAMAKRISHNA MISSION } \\
\text { VIVEKANANDA } \\
\text { EDUCATIONAL AND } \\
\text { RESEARCH INSTITUTE, } \\
\text { West Bengal. }\end{array}$ & 93 & 13 & 0.0280 \\
\hline 3 & $\begin{array}{l}\text { BANASTHALI VIDYAPITH } \\
\text { Rajasthan }\end{array}$ & 389 & 22 & 0.0113 \\
\hline 4 & $\begin{array}{l}\text { KONERU LAKSHMAIAH } \\
\text { EDUCATION } \\
\text { FOUNDATION, GUNTUR, } \\
\text { Andhra Pradesh. }\end{array}$ & 1,180 & 23 & 0.0039 \\
\hline 5 & $\begin{array}{l}\text { INDIRA GANDHI } \\
\text { NATIONAL OPEN } \\
\text { UNIVERSITY } \\
\text { New Delhi, Delhi. }\end{array}$ & 498 & - & 0.00 \\
\hline 6 & $\begin{array}{l}\text { SRM INSTITUTE OF } \\
\text { SCIENCE AND } \\
\text { TECHNOLOGY, } \\
\text { Chennai, Tamil Nadu. }\end{array}$ & 3,287 & 51 & 0.0031 \\
\hline 7 & $\begin{array}{l}\text { MADURAI KAMARAJ } \\
\text { UNIVERSITY, Madurai, } \\
\text { Tamil Nadu. }\end{array}$ & 182 & 11 & 0.0121 \\
\hline 8 & $\begin{array}{l}\text { SRI RAMACHANDRA } \\
\text { INSTITUTE OF HIGHER } \\
\text { EDUCATION AND } \\
\text { RESEARCH, Chennai, Tamil } \\
\text { Nadu. }\end{array}$ & 729 & 52 & 0.0143 \\
\hline 9 & $\begin{array}{l}\text { SHIVAJI UNIVERSITY, } \\
\text { Kolhapur, } \\
\text { Maharashtra. }\end{array}$ & 201 & 13 & 0.0130 \\
\hline
\end{tabular}

8. ANALYSIS OF INDIAN TOP NAAC A++ UNIVERSITIES RESEARCH PUBLICATIONS USING ABC MODEL OF RESEARCH PRODUCTIVITY :

The annual research productivity of an organization can be measured using $\mathrm{ABC}$ model of average annual research performance [16-17]. According to $\mathrm{ABC}$ model, if $\mathrm{A}$ is the number of Journal papers, $\mathrm{B}$ is the number of Books, and C is the total number of Book Chapters and Conference Proceedings papers of an organization for a given year then the institutional average annual research index $(\alpha)$ can be calculated using the relationship $\alpha=\{[2 \mathrm{~A}+(\mathrm{B}+\mathrm{C})] / 3\} / \mathrm{N}$, where $\mathrm{N} \mathrm{s}$ the number of faculty members of the organization. The institutional average annual research index of these nine A++ universities are calculated using the data given in the respective self-study reports using $\mathrm{ABC}$ model and depicted in table 16.

Table 16: Institutional average annual research index as per ABC model

\begin{tabular}{|l|l|l|l|l|l|}
\hline S. No. & University \& State & $\begin{array}{l}\text { No. of } \\
\text { Teaching } \\
\text { Faculty } \\
\text { members } \\
\text { (N) }\end{array}$ & $\begin{array}{l}\text { Annual } \\
\text { Average } \\
\text { Journal } \\
\text { Articles } \\
\text { (A) }\end{array}$ & $\begin{array}{l}\text { Annual } \\
\text { Average } \\
\text { other } \\
\text { Articles } \\
\text { (B+C) }\end{array}$ & $\begin{array}{l}\text { Annual } \\
\text { Research } \\
\text { Productivity } \\
\text { Index ( } \boldsymbol{\alpha})\end{array}$ \\
\hline 1 & $\begin{array}{l}\text { INDIAN INSTITUTE OF } \\
\text { SCIENCE, Bangalore, } \\
\text { Karnataka. }\end{array}$ & 430 & 4.23 & 1.43 & 3.3 \\
\hline
\end{tabular}




\begin{tabular}{|c|c|c|c|c|c|}
\hline 2 & $\begin{array}{l}\text { RAMAKRISHNA } \\
\text { MISSION } \\
\text { VIVEKANANDA } \\
\text { EDUCATIONAL AND } \\
\text { RESEARCH INSTITUTE, } \\
\text { West Bengal. } \\
\end{array}$ & 93 & 1.57 & 0.62 & 1.25 \\
\hline 3 & $\begin{array}{l}\text { BANASTHALI } \\
\text { VIDYAPITH } \\
\text { Rajasthan }\end{array}$ & 389 & 0.93 & 0.29 & 0.72 \\
\hline 4 & $\begin{array}{l}\text { KONERU LAKSHMAIAH } \\
\text { EDUCATION } \\
\text { FOUNDATION, GUNTUR, } \\
\text { Andhra Pradesh. }\end{array}$ & 1,180 & 1.25 & 0.78 & 1.09 \\
\hline 5 & $\begin{array}{l}\text { INDIRA GANDHI } \\
\text { NATIONAL OPEN } \\
\text { UNIVERSITY } \\
\text { New Delhi, Delhi. }\end{array}$ & 498 & 2.18 & 0.26 & 1.54 \\
\hline 6 & $\begin{array}{l}\text { SRM INSTITUTE OF } \\
\text { SCIENCE AND } \\
\text { TECHNOLOGY, } \\
\text { Chennai, Tamil Nadu. }\end{array}$ & 3,287 & 0.82 & 0.26 & 0.64 \\
\hline 7 & $\begin{array}{l}\text { MADURAI KAMARAJ } \\
\text { UNIVERSITY, Madurai, } \\
\text { Tamil Nadu. }\end{array}$ & 182 & 1.6 & 1.37 & 1.52 \\
\hline 8 & $\begin{array}{l}\text { SRI RAMACHANDRA } \\
\text { INSTITUTE OF HIGHER } \\
\text { EDUCATION AND } \\
\text { RESEARCH, Chennai, } \\
\text { Tamil Nadu. }\end{array}$ & 729 & 0.98 & 0.05 & 0.67 \\
\hline 9 & $\begin{array}{l}\text { SHIVAJI UNIVERSITY, } \\
\text { Kolhapur, } \\
\text { Maharashtra. }\end{array}$ & 201 & 1.88 & 0.59 & 1.45 \\
\hline
\end{tabular}

Table 17 : Re-ranking of A++ graded Universities based on their average Annual Research Productivity

\begin{tabular}{|l|l|l|l|l|}
\hline S. No. & University \& State & $\begin{array}{l}\text { No. of Teaching } \\
\text { Faculty } \\
\text { members (N) }\end{array}$ & $\begin{array}{l}\text { Annual Research } \\
\text { Productivity Index } \\
(\boldsymbol{\alpha})\end{array}$ & $\begin{array}{l}\text { Ranking based } \\
\text { on (a) }\end{array}$ \\
\hline 1 & $\begin{array}{l}\text { INDIAN INSTITUTE OF } \\
\text { SCIENCE, Bangalore, } \\
\text { Karnataka. }\end{array}$ & 430 & 3.3 & First \\
\hline 2 & $\begin{array}{l}\text { RAMAKRISHNA } \\
\text { MISSION } \\
\text { VIVEKANANDA } \\
\text { EDUCATIONAL AND } \\
\text { RESEARCH INSTITUTE, } \\
\text { West Bengal. }\end{array}$ & 93 & 1.25 & Fifth \\
\hline 3 & $\begin{array}{l}\text { BANASTHALI } \\
\text { VIDYAPITH } \\
\text { Rajasthan }\end{array}$ & 389 & 0.72 & Seventh \\
\hline 4 & $\begin{array}{l}\text { KONERU LAKSHMAIAH } \\
\text { EDUCATION } \\
\text { FOUNDATION, GUNTUR, } \\
\text { Andhra Pradesh. }\end{array}$ & 1,180 & 1.09 & Sixth \\
\hline
\end{tabular}




\begin{tabular}{|l|l|l|l|l|}
\hline 5 & $\begin{array}{l}\text { INDIRA GANDHI } \\
\text { NATIONAL OPEN } \\
\text { UNIVERSITY } \\
\text { New Delhi, Delhi. }\end{array}$ & 498 & 1.54 & Second \\
\hline 6 & $\begin{array}{l}\text { SRM INSTITUTE OF } \\
\text { SCIENCE AND } \\
\text { TECHNOLOGY, } \\
\text { Chennai, Tamil Nadu. }\end{array}$ & 3,287 & 0.64 & Ninth \\
\hline 7 & $\begin{array}{l}\text { MADURAI KAMARAJ } \\
\text { UNIVERSITY, Madurai, } \\
\text { Tamil Nadu. }\end{array}$ & 182 & 1.52 & Third \\
\hline 8 & $\begin{array}{l}\text { SRI RAMACHANDRA } \\
\text { INSTITUTE OF HIGHER } \\
\text { EDUCATION AND } \\
\text { RESEARCH, Chennai, } \\
\text { Tamil Nadu. }\end{array}$ & 729 & 0.67 & Eighth \\
\hline 9 & $\begin{array}{l}\text { SHIVAJI UNIVERSITY, } \\
\text { Kolhapur, } \\
\text { Maharashtra. }\end{array}$ & 201 & 1.45 & Fourth \\
\hline
\end{tabular}

\section{ANALYSIS OF LEADERSHIP AS ROLE MODEL :}

The ability and quality of leader in any organization is one of the important factors of organizational productivity. As per the Theory of Accountability [23-30], a role model is needed in an organization who has to be exceptional performer so that others will be motivated and re-define their performance targets. Usually, the leader of the organization is expected as a role model and hence he will get a moral right to lead others by fixing individual and team targets. In universities, vice-chancellors are expected to be role models for teachers and researchers by means of their involvement in administrative, teaching, and research activities. Since vice-chancellor is an experienced senior professor, his involvement in research and guiding is very much required and appreciated in improving university research productivity. Self-contribution along with enhancing others productivity is the important characteristic required to a competitive and winning leader. Hence, in this section, the research productivity of vicechancellors of these NAAC A++ universities during last five years are determined by calculating their individual average annual research index $(\beta)$. The calculation is based on Google scholar data available as on $30^{\text {th }}$ April 2021. Table 18 lists the number of journal publications of the Vice-Chancellors, and the citations they received during the last 5 years and their H-Index value during the last 5 years as per google scholar citation calculation. Table 19 lists the individual average annual research index $(\beta)$ of these vice-chancellors/directors calculated using the idea given by ABC theory of research productivity of an organization and individuals [31-32]. Comparative publication and Citation rankings of Vicechancellors of these universities is given in table 18, which is based on last five years of open access data (2016-2020) collected from Google scholar and other public websites.

Table 18: Leadership of the University as on 30/April 2021

\begin{tabular}{|l|l|l|l|l|l|}
\hline S. No. & University/ Institute & $\begin{array}{l}\text { Name of Vice } \\
\text { Chancellor/Director } \\
\text { as per NAAC-SSR }\end{array}$ & $\begin{array}{l}\text { Publications } \\
\text { during last } \\
\text { 5 Years } \\
\mathbf{( 1 6 - 2 0 )}\end{array}$ & $\begin{array}{l}\text { Citations } \\
\text { during } \\
\text { last 5 } \\
\text { Years }\end{array}$ & $\begin{array}{l}\text { H-Index } \\
\text { during } \\
\text { last 5 } \\
\text { Years }\end{array}$ \\
\hline 1 & $\begin{array}{l}\text { INDIAN INSTITUTE OF } \\
\text { SCIENCE, Bangalore, } \\
\text { Karnataka. }\end{array}$ & $\begin{array}{l}\text { Govindan } \\
\text { Rangarajan } \\
\text { Professor of } \\
\text { Mathematics, }\end{array}$ & 14 & 1,374 & 22 \\
\hline 2 & $\begin{array}{l}\text { RAMAKRISHNA } \\
\text { MISSION } \\
\text { VIVEKANANDA }\end{array}$ & $\begin{array}{l}\text { Swami } \\
\text { Atmapriyananda }\end{array}$ & 0 & 0 & 0 \\
\hline
\end{tabular}




\begin{tabular}{|c|c|c|c|c|c|}
\hline & $\begin{array}{l}\text { EDUCATIONAL AND } \\
\text { RESEARCH INSTITUTE, } \\
\text { West Bengal. }\end{array}$ & & & & \\
\hline 3 & $\begin{array}{l}\text { BANASTHALI } \\
\text { VIDYAPITH } \\
\text { Rajasthan, }\end{array}$ & $\begin{array}{l}\text { Aditya Shastri, } \\
\text { Professor of } \\
\text { Computer Science }\end{array}$ & 0 & 0 & 0 \\
\hline 4 & $\begin{array}{l}\text { KONERU } \\
\text { LAKSHMAIAH } \\
\text { EDUCATION } \\
\text { FOUNDATION } \\
\text { Andhra Pradesh }\end{array}$ & $\begin{array}{l}\text { L.S.S. Reddy is an } \\
\text { eminent Professor in } \\
\text { Computer Science } \\
\text { and Engineering }\end{array}$ & 7 & 34 & 13 \\
\hline 5 & $\begin{array}{l}\text { INDIRA GANDHI } \\
\text { NATIONAL OPEN } \\
\text { UNIVERSITY } \\
\text { Delhi, New Delhi, }\end{array}$ & $\begin{array}{l}\text { Nageshwar Rao, } \\
\text { Professor of } \\
\text { Business } \\
\text { Management \& } \\
\text { Finance }\end{array}$ & 1 & 0 & 0 \\
\hline 6 & $\begin{array}{l}\text { SRM INSTITUTE OF } \\
\text { SCIENCE AND } \\
\text { TECHNOLOGY } \\
\text { Tamil Nadu, Chennai, }\end{array}$ & Sandeep Sancheti & 3 & 66 & 4 \\
\hline 7 & $\begin{array}{l}\text { MADURAI KAMARAJ } \\
\text { UNIVERSITY } \\
\text { Tamil Nadu }\end{array}$ & $\begin{array}{l}\text { Muthukalingan } \\
\text { Krishnan, } \\
\text { Environmental } \\
\text { Biotechnology, }\end{array}$ & 35 & 1,259 & 15 \\
\hline 8 & $\begin{array}{l}\text { SRI RAMACHANDRA } \\
\text { INSTITUTE OF HIGHER } \\
\text { EDUCATION AND } \\
\text { RESEARCH } \\
\text { Tamil Nadu }\end{array}$ & $\begin{array}{l}\text { P. V. } \\
\text { Vijayaraghavan }\end{array}$ & 7 & $\begin{array}{l}50 \\
-\end{array}$ & 5 \\
\hline 9 & $\begin{array}{l}\text { SHIVAJI UNIVERSITY, } \\
\text { Kolhapur, } \\
\text { Maharashtra. }\end{array}$ & $\begin{array}{l}\text { Digambar } \\
\text { Tukaram } \\
\text { Shirke } \\
\end{array}$ & 23 & 407 & 12 \\
\hline
\end{tabular}

Table 19: Average annual research index of last five years of Vice-chancellors of NAAC A++ universities (based on Google scholar data) as on $30^{\text {th }}$ April 2021

\begin{tabular}{|c|c|c|c|c|}
\hline S. No. & University/Institute & $\begin{array}{l}\text { Name of Vice } \\
\text { Chancellor/Director } \\
\text { as per NAAC-SSR }\end{array}$ & $\begin{array}{l}\text { Publications } \\
\text { during last } 5 \\
\text { Years (2016- } \\
\text { 2020) }\end{array}$ & $\begin{array}{l}\text { Average annual } \\
\text { research index } \\
(\beta)= \\
(2 \mathrm{~A}+5 \mathrm{~B}+\mathrm{C}) / 5 \\
(\text { Rank) }\end{array}$ \\
\hline 1 & $\begin{array}{l}\text { INDIAN INSTITUTE OF } \\
\text { SCIENCE, Bangalore, } \\
\text { Karnataka. }\end{array}$ & $\begin{array}{l}\text { Govindan } \\
\text { Rangarajan } \\
\text { Professor of } \\
\text { Mathematics, }\end{array}$ & $\begin{array}{l}\mathrm{A}-14 \\
\mathrm{~B}-0 \\
\mathrm{C}-1\end{array}$ & 5.8 (III) \\
\hline 2 & $\begin{array}{l}\text { RAMAKRISHNA } \\
\text { MISSION } \\
\text { VIVEKANANDA } \\
\text { EDUCATIONAL AND } \\
\text { RESEARCH INSTITUTE, } \\
\text { West Bengal. }\end{array}$ & $\begin{array}{l}\text { Swami } \\
\text { Atmapriyananda }\end{array}$ & $\begin{array}{l}\mathrm{A}-0 \\
\mathrm{~B}-0 \\
\mathrm{C}-0\end{array}$ & $0(\mathrm{IX})$ \\
\hline 3 & $\begin{array}{l}\text { BANASTHALI } \\
\text { VIDYAPITH } \\
\text { Rajasthan, }\end{array}$ & $\begin{array}{l}\text { Aditya Shastri, } \\
\text { Professor of } \\
\text { Computer Science }\end{array}$ & $\begin{array}{l}A-1 \\
B-0 \\
C-0\end{array}$ & 0.4 (VII) \\
\hline
\end{tabular}




\begin{tabular}{|c|c|c|c|c|}
\hline 4 & $\begin{array}{l}\text { KONERU LAKSHMAIAH } \\
\text { EDUCATION } \\
\text { FOUNDATION } \\
\text { Andhra Pradesh }\end{array}$ & $\begin{array}{l}\text { L.S.S. Reddy is an } \\
\text { eminent Professor in } \\
\text { Computer Science } \\
\text { and Engineering }\end{array}$ & $\begin{array}{l}\mathrm{A}-7 \\
\mathrm{~B}-0 \\
\mathrm{C}-0\end{array}$ & 2.8 (IV) \\
\hline 5 & $\begin{array}{l}\text { INDIRA GANDHI } \\
\text { NATIONAL OPEN } \\
\text { UNIVERSITY } \\
\text { Delhi, New Delhi, }\end{array}$ & $\begin{array}{l}\text { Nageshwar Rao, } \\
\text { Professor of Business } \\
\text { Management \& } \\
\text { Finance }\end{array}$ & $\begin{array}{l}\mathrm{A}-1 \\
\mathrm{~B}-0 \\
\mathrm{C}-0\end{array}$ & 0.4 (VII) \\
\hline 6 & $\begin{array}{l}\text { SRM INSTITUTE OF } \\
\text { SCIENCE AND } \\
\text { TECHNOLOGY } \\
\text { Tamil Nadu, Chennai, }\end{array}$ & $\begin{array}{l}\text { Sandeep Sancheti, } \\
\text { Professor of } \\
\text { Electronics \& } \\
\text { Communications }\end{array}$ & $\begin{array}{l}\mathrm{A}-3 \\
\mathrm{~B}-1 \\
\mathrm{C}-0\end{array}$ & $2.2(\mathrm{VI})$ \\
\hline 7 & $\begin{array}{l}\text { MADURAI KAMARAJ } \\
\text { UNIVERSITY } \\
\text { Tamil Nadu }\end{array}$ & $\begin{array}{l}\text { Uthukalingan } \\
\text { Krishnan, } \\
\text { Environmental } \\
\text { Biotechnology, }\end{array}$ & $\begin{array}{l}\mathrm{A}-35 \\
\mathrm{~B}-0 \\
\mathrm{C}-0\end{array}$ & 14 (I) \\
\hline 8 & $\begin{array}{l}\text { SRI RAMACHANDRA } \\
\text { INSTITUTE OF HIGHER } \\
\text { EDUCATION AND } \\
\text { RESEARCH } \\
\text { Tamil Nadu }\end{array}$ & $\begin{array}{l}\text { P. V. } \\
\text { Vijayaraghavan, } \\
\text { Health Science }\end{array}$ & $\begin{array}{l}\text { A }-7 \\
\text { B }-0 \\
\text { C }-0\end{array}$ & 2.8 (IV) \\
\hline 9 & $\begin{array}{l}\text { SHIVAJI UNIVERSITY, } \\
\text { Kolhapur, } \\
\text { Maharashtra. }\end{array}$ & $\begin{array}{l}\text { Digambar Tukaram } \\
\text { Shirke, } \\
\text { Statistics }\end{array}$ & $\begin{array}{l}\mathrm{A}-23 \\
\mathrm{~B}-0 \\
\mathrm{C}-0\end{array}$ & 9.2 (II) \\
\hline
\end{tabular}

Table 20 : Comparative publication and Citation ranking on last five years data (2016-2020)

\begin{tabular}{|c|c|c|c|c|c|}
\hline $\begin{array}{l}\text { S. } \\
\text { No. }\end{array}$ & University/Institute & $\begin{array}{l}\text { Name of Vice } \\
\text { Chancellor/ } \\
\text { Director as per } \\
\text { NAAC-SSR }\end{array}$ & $\begin{array}{l}\text { Comparative } \\
\text { Publication } \\
\text { Ranking }\end{array}$ & $\begin{array}{c}\text { Comparative } \\
\text { Citation } \\
\text { Ranking }\end{array}$ & $\begin{array}{c}\text { Grade } \\
\text { points } \\
\text { scored in } \\
\text { Criterion } \\
6\end{array}$ \\
\hline 1 & $\begin{array}{l}\text { INDIAN INSTITUTE OF } \\
\text { SCIENCE, Bangalore, } \\
\text { Karnataka. }\end{array}$ & $\begin{array}{l}\text { Govindan } \\
\text { Rangarajan } \\
\text { Professor of } \\
\text { Mathematics, }\end{array}$ & III & $\mathrm{I}$ & 3.57 \\
\hline 2 & $\begin{array}{l}\text { RAMAKRISHNA } \\
\text { MISSION } \\
\text { VIVEKANANDA } \\
\text { EDUCATIONAL AND } \\
\text { RESEARCH } \\
\text { INSTITUTE, } \\
\text { West Bengal. }\end{array}$ & $\begin{array}{l}\text { Swami } \\
\text { Atmapriyananda }\end{array}$ & IX & - & 3.70 \\
\hline 3 & $\begin{array}{l}\text { BANASTHALI } \\
\text { VIDYAPITH } \\
\text { Rajasthan, }\end{array}$ & $\begin{array}{l}\text { Aditya Shastri, } \\
\text { Professor of } \\
\text { Computer Science }\end{array}$ & VII & - & 3.60 \\
\hline 4 & $\begin{array}{l}\text { KONERU } \\
\text { LAKSHMAIAH } \\
\text { EDUCATION } \\
\text { FOUNDATION } \\
\text { Andhra Pradesh } \\
\end{array}$ & $\begin{array}{l}\text { L.S.S. Reddy is an } \\
\text { eminent Professor } \\
\text { in Computer } \\
\text { Science and } \\
\text { Engineering }\end{array}$ & IV & VI & 3.50 \\
\hline 5 & $\begin{array}{l}\text { INDIRA GANDHI } \\
\text { NATIONAL OPEN } \\
\text { UNIVERSITY }\end{array}$ & $\begin{array}{l}\text { Nageshwar Rao, } \\
\text { Professor of } \\
\text { Business }\end{array}$ & VII & - & 3.97 \\
\hline
\end{tabular}




\begin{tabular}{|l|l|l|l|l|l|}
\hline & Delhi, New Delhi, & $\begin{array}{l}\text { Management \& } \\
\text { Finance }\end{array}$ & & & \\
\hline 6 & $\begin{array}{l}\text { SRM INSTITUTE OF } \\
\text { SCIENCE AND } \\
\text { TECHNOLOGY } \\
\text { Tamil Nadu, Chennai, }\end{array}$ & $\begin{array}{l}\text { Sandeep Sancheti, } \\
\text { Professor of } \\
\text { Electronics \& } \\
\text { Communications }\end{array}$ & VI & IV & 2.88 \\
\hline 7 & $\begin{array}{l}\text { MADURAI KAMARAJ } \\
\text { UNIVERSITY } \\
\text { Tamil Nadu }\end{array}$ & $\begin{array}{l}\text { Uthukalingan } \\
\text { Krishnan, } \\
\text { Environmental } \\
\text { Biotechnology, }\end{array}$ & I & II & 3.63 \\
\hline 8 & $\begin{array}{l}\text { SRI RAMACHANDRA } \\
\text { INSTITUTE OF HIGHER } \\
\text { EDUCATION AND } \\
\text { RESEARCH } \\
\text { Tamil Nadu }\end{array}$ & $\begin{array}{l}\text { Vijayaraghavan, } \\
\text { Health } \\
\text { Science }\end{array}$ & IV & V & 3.49 \\
\hline 9 & $\begin{array}{l}\text { SHIVAJI UNIVERSITY, } \\
\text { Kolhapur, } \\
\text { Maharashtra. }\end{array}$ & $\begin{array}{l}\text { Digambar } \\
\text { Tukaram } \\
\text { Shirke }\end{array}$ & II & III & 2.95 \\
\hline
\end{tabular}

10. DISCUSSION :

\subsection{Critical Comments on NAAC A++ Universities Performance \& Assessment:}

(1) Based on the datasheets of NAAC assessments, it is observed that some of the universities have scored full grade points in certain criteria (Table 3). Similarly, many universities in the list have scored full grade points in many Key indicators within a given criterion (Table 5). This kind of full score indicates that no further innovations and improvements are required by such universities. Other universities and institutions will consider the current quality level of such criteria of these universities is reached the ideal level and may wrongly interpret as a benchmark and consider that there is no scope for further improvement.

(2) Based on the information available in tables 16 and 17, the annual research productivity index is less than one for many privately funded universities. This shows that private universities are focussing mostly on commercial aspects to generate profits for sustainability, unlike publicly funded universities are mainly depend on government subsidies. The percentage of Ph.D. qualified faculty members in privately-funded NAAC A++ universities are less compared to publicly funded NAAC A++ universities (Table 11). This shows that public A++ universities are more research focussed compared to private A++ universities. Again, this imparity may be due to their challenge of sustainability and growth by self-generated funds and hence to follow low-cost strategy.

(3) In the criteria of Research, Innovations, and Extension, the research capability and performance should be measured based on the research output than other aspects to the mobilization of funds, etc. This is because of the fact that research output in terms of publication and patents is tangible and quantifiable and can be measured using systematic metrics where are intangible key indicators cannot be measured in quantitative terms. The research funding will usually increase the research output. Thus, assessment based on the amount of research output (Research Publications and Awards) of an organization should be stressed compared to other key indicators like Promotion of Research and Facilities, Resource Mobilization for Research, Innovation Ecosystem, Consultancy, Extension Activities, and Collaboration, which are intangible and unquantifiable.

(4) Research output of an individual and organization can be measured using the number of scholarly articles (A), number of edited books (B), and number of edited Conference papers, chapters, case studies, or patents (C) by giving different weightage as per ABC model of research productivity.

(5) According to many organizational theories, a leader in the organization must inspire other stakeholders of the organization through his leadership qualities. In any type of university, the vicechancellor is the academic, administrative, and research leader and based on his/her academic \& research achievements. A vice-chancellor through his/her life-long contribution to the higher education field as a teacher, researcher, guide, and mentor, should continue as a role model to students and faculty members through his/her exceptional contribution to the objective of the university, which is guiding the students and creating new knowledge through self-contribution to research \& innovation. Such 
leaders can motivate other young professors as role models [33] and contributes to the higher performance of the university. Accordingly, the individual research contribution of vice-chancellors of NAAC A++ universities is studied. Tables 18, and 19 shows that the research contribution by vicechancellors based on individual research productivity index as a role model is unsatisfactory as compared to the optimum expectation [33,34]. However, some vice-chancellors have not made any contribution to research and publication during the last 5 years. Further, the grade points allotted to the universities for the key indicator "Research Publications and Awards" which is usually based on the research output of the university have ambiguity among the 9 universities under consideration.

(6) Table 20 also contains the grade points scored by these nine NAAC A++ universities under the sixth criterion "Governance, Leadership, and Management". The result shows that there is no correlation between research role models and administrative role models in the higher education system. Such universities might have other research role models who might have inspired researchers for the enhanced research productivity.

(7) Research productivity of an organization of higher education that has the dual responsibility of teaching \& research can be improved by providing additional incentive-based faculty compensation that stimulates faculty members to teamwork by dedicating more time and resources to research activities [34-35]. Such annual performance based compensation can enhance faculty contribution for research and publication [36-38].

(8) While observing deep into allotted credits for individual key indicators by comparing self-study reports of these universities, there is a discrepancy between the universities either due to errors included by different expert team inspection or due to intentional priorities given to some universities by the NAAC office due to reasons like brand image, lobby, influence, or any other black ocean strategy of these universities [39].

(9) The average annual research index of the Vice-chancellors/Directors of these universities (Table 19) is found to be low against the general requirement [32]. Further, they failed to publish at least two scholarly publications per year on an average for five years. Many Vice-chancellors failed to prove that they are effective role models for their researchers. Still, based on various other reasons they might have elevated to the academic leadership position. As per the UGC norms, a Vice-chancellor, (being a professor also in a university) is expected to guide up to 8 research scholars for their Ph.D. and hence is expected to contribute to the scholarly research field by means of at least a few scholarly publications. The failure to this raises questions about their leadership abilities, especially in the universities that have research as one of their major objectives.

(10) The research publications, university H-Index, and total Citation counts should be taken from noncommercial citation indexing agencies like google scholar as a policy to avoid lobbying of commercial agencies such as Scopus and Web of Science.

(11) Indian Institute of Science, being the top institution in the country as per NIRF, could not score full score in at least in one criterion. But other five universities out of nine NAAC A++ universities have obtained full scores in one criterion respectively. This disparity in comparative criteria-wise results among the A++ universities is mainly due to the considerable difference between the background of peer inspection team members.

(12) The black ocean strategy based on unethical practices [39] used by some universities might have influenced in this assessment and placing the universities on top letter grades. For example, the appointment of former AICTE/UGC chairman in Board of Directors team or as Chancellor/Vicechancellor of the university, appointment of current/former Directors of NAAC as the Honorary professors of some universities for the publication of their scholarly papers to get publication credits, etc.

(13) Weakness in NAAC policy of assessment in considering the research output and evaluating public and private universities on the same scale even if they have differences in terms of funding sources and service objectives is also seen in NAAC accreditation results.

(14) Since the model of research publications are changing with technology from $20^{\text {th }}$-century subscription based journal publications to $21^{\text {st }}$-century open access journal publications, the concept of focus on publication in commercial journals by transferring authors copyright to publishers or paying huge Article processing charge (APC) for journals to retain copyright should change and NAAC accreditation should not give weightage or compulsion for commercial indexing agencies such as 
Scopus and Web of Science. NAAC should give due consideration for Google Scholar indexing of scholarly publications and Google scholar H-index.

(15) The very low value of the annual average publications per author (APPA) also called annual research productivity of these A++ graded universities indicates that except the Indian Institute of Science, Bangalore (table 17), the research in other eight universities are in the nascent stage with less than two papers per faculty per year in public funded universities and with less than one paper per faculty per year in private self-funded universities. This indicates that private universities show the least responsibility toward their contribution of offering research focussed higher education system.

(16) Similarly, the average citation per faculty per year is close to one except for the Indian Institute of Science, Bangalore which is 35, and Sri Ramachandra Institute of Higher Education and Research, Chennai which is 5 (Table 14). The citation shows the quality and continuation of research in the research topics. With such low performance also, these eight universities could compete with the Indian Institute of Science, Bangalore, and comparatively earned almost equal scores in the NAAC assessment. (17) As per table 21, there is a considerable difference in the grading pattern by NAAC inspection committees, compared to the average number of publications per faculty per year and the average number of citations per faculty per year.

Table 21: Comparison of Grade points scored in research and publication key indicator with average annual publication per faculty and average annual citation per faculty.

\begin{tabular}{|c|c|c|c|c|}
\hline $\begin{array}{l}\text { S. } \\
\text { No. }\end{array}$ & University \& State & $\begin{array}{l}\text { Grade points of } \\
\text { Research Publications } \\
\text { and Awards Key } \\
\text { Indicator out of 4.0* }\end{array}$ & $\begin{array}{l}\text { Average } \\
\text { Annual } \\
\text { Publication } \\
\text { per Faculty }\end{array}$ & $\begin{array}{l}\text { Average } \\
\text { Annual } \\
\text { Citation per } \\
\text { Faculty } \\
\end{array}$ \\
\hline 1 & $\begin{array}{l}\text { INDIAN INSTITUTE OF } \\
\text { SCIENCE, Bangalore, } \\
\text { Karnataka. }\end{array}$ & 3.66 & 4.23 & 35 \\
\hline 2 & $\begin{array}{l}\text { RAMAKRISHNA MISSION } \\
\text { VIVEKANANDA } \\
\text { EDUCATIONAL AND } \\
\text { RESEARCH INSTITUTE, } \\
\text { West Bengal. }\end{array}$ & 2.48 & 1.57 & 0.71 \\
\hline 3 & $\begin{array}{l}\text { BANASTHALI VIDYAPITH } \\
\text { Rajasthan, Banasthali } \\
\text { Vidyapith, 304022, P.O. } \\
\text { Banasthali Vidyapith, Dist. } \\
\text { Tonk, Rajasthan }\end{array}$ & 2.95 & 0.93 & 1.15 \\
\hline 4 & $\begin{array}{l}\text { KONERU LAKSHMAIAH } \\
\text { EDUCATION } \\
\text { FOUNDATION, GUNTUR, } \\
\text { Andhra Pradesh. }\end{array}$ & 2.67 & 1.25 & 0.75 \\
\hline 5 & $\begin{array}{l}\text { INDIRA GANDHI } \\
\text { NATIONAL OPEN } \\
\text { UNIVERSITY } \\
\text { New Delhi, Delhi. }\end{array}$ & 2.69 & 2.18 & 0.93 \\
\hline 6 & $\begin{array}{l}\text { SRM INSTITUTE OF } \\
\text { SCIENCE AND } \\
\text { TECHNOLOGY, } \\
\text { Chennai, Tamil Nadu. }\end{array}$ & 2.71 & 0.82 & 1.33 \\
\hline 7 & $\begin{array}{l}\text { MADURAI KAMARAJ } \\
\text { UNIVERSITY, Madurai, } \\
\text { Tamil Nadu. }\end{array}$ & 3.31 & 1.6 & 1.46 \\
\hline 8 & $\begin{array}{l}\text { SRI RAMACHANDRA } \\
\text { INSTITUTE OF HIGHER } \\
\text { EDUCATION AND } \\
\text { RESEARCH, Chennai, }\end{array}$ & 3.09 & 0.98 & 4.7 \\
\hline
\end{tabular}




\begin{tabular}{|l|l|l|l|l|}
\hline & Tamil Nadu. & & & \\
\hline 9 & $\begin{array}{l}\text { SHIVAJI UNIVERSITY, } \\
\text { Kolhapur, } \\
\text { Maharashtra. }\end{array}$ & 2.93 & 1.88 & 1.49 \\
\hline
\end{tabular}

\subsection{SWOC Analysis as per NAAC Evaluation :}

In this section, the strength, weakness, opportunities and challenges [40-41] of these NAAC A++ Universities are discussed based on the scores they received in the key indicator of research publication and awards of Research, Innovations and Extension criterion and is depicted in table 22.

Table 22: SWOC analysis of A++ universities based on NAAC Assessment data related to research and publication key indicator

\begin{tabular}{|c|c|c|c|c|c|}
\hline $\begin{array}{l}\text { S. } \\
\text { No. }\end{array}$ & University & Strength & Weakness & Opportunities & Challenges \\
\hline 1 & $\begin{array}{l}\text { INDIAN } \\
\text { INSTITUTE OF } \\
\text { SCIENCE, } \\
\text { Bangalore, } \\
\text { Karnataka. }\end{array}$ & $\begin{array}{l}\text { (1) Scored full } \\
\text { marks in } \\
\text { Promotion of } \\
\text { Research and } \\
\text { Facilities criteria } \\
\text { (2) Scored full } \\
\text { marks in } \\
\text { Resource } \\
\text { Mobilization for } \\
\text { Research. } \\
\text { (3) Scored full } \\
\text { marks in } \\
\text { Innovation } \\
\text { Ecosystem. } \\
\text { (4) Scored full } \\
\text { marks in } \\
\text { Consultancy. } \\
\text { (5) Scored full } \\
\text { marks in } \\
\text { Collaboration. } \\
\text { (6) Strong } \\
\text { Leadership as } \\
\text { role model in } \\
\text { terms of research } \\
\text { \& publication }\end{array}$ & $\begin{array}{l}\text { (1) Scored } \\
\text { comparatively } \\
\text { less marks in } \\
\text { Research } \\
\text { Publications and } \\
\text { Awards even if it } \\
\text { has scored } \\
\text { (2) Scored very } \\
\text { less marks in } \\
\text { Extension } \\
\text { Activities. }\end{array}$ & $\begin{array}{l}\text { (1) Further } \\
\text { improvement } \\
\text { possible to } \\
\text { publish more } \\
\text { papers by setting } \\
\text { the targets to } \\
\text { research faculty } \\
\text { members. } \\
\text { (2) All faculty } \\
\text { members have } \\
\text { Ph.D. degree. } \\
100 \text { years } \\
\text { Academic } \\
\text { reputation. }\end{array}$ & $\begin{array}{l}\text { (1) } \\
\text { Improving } \\
\text { Citations by } \\
\text { working in } \\
\text { futuristic \& } \\
\text { cutting-edge } \\
\text { research } \\
\text { area } \\
\text { (2) } \\
\text { Improving } \\
\text { faculty } \\
\text { publications } \\
\text { further to } \\
\text { maintain the } \\
\text { current } \\
\text { status. }\end{array}$ \\
\hline 2 & $\begin{array}{l}\text { RAMAKRISHNA } \\
\text { MISSION } \\
\text { VIVEKANANDA } \\
\text { EDUCATIONAL } \\
\text { AND } \\
\text { RESEARCH } \\
\text { INSTITUTE, } \\
\text { West Bengal. }\end{array}$ & $\begin{array}{l}\text { (1) Scored full } \\
\text { marks in } \\
\text { Promotion of } \\
\text { Research and } \\
\text { Facilities. } \\
\text { (2) Scored full } \\
\text { marks in } \\
\text { Consultancy } \\
\text { (3) Scored full } \\
\text { marks in } \\
\text { Extension } \\
\text { Activities } \\
\text { (4) Scored full } \\
\text { marks in } \\
\text { Collaboration. }\end{array}$ & $\begin{array}{l}\text { (1) Scored less } \\
\text { marks Resource } \\
\text { Mobilization for } \\
\text { Research. } \\
\text { (2) Scored less } \\
\text { marks in } \\
\text { Research } \\
\text { Publications and } \\
\text { Awards. }\end{array}$ & $\begin{array}{l}\text { (1) More } \\
\text { Research focus } \\
\text { by implementing } \\
\text { faculty } \\
\text { accountability } \\
\text { policies. } \\
\text { (2) Long } \\
\text { standing brand in } \\
\text { the State. } \\
\text { (3) Easy access } \\
\text { to research funds } \\
\text { by public. }\end{array}$ & $\begin{array}{l}\text { (1) } \\
\text { Conversion } \\
\text { of Ph.D. } \\
\text { ratio from } \\
80 \% \text { to } \\
100 \% \text {. } \\
\text { (2) } \\
\text { Improving } \\
\text { average } \\
\text { annual } \\
\text { faculty } \\
\text { publication } \\
\text { from current } \\
1.57 \text { to 5.0. }\end{array}$ \\
\hline
\end{tabular}




\begin{tabular}{|c|c|c|c|c|c|}
\hline & & $\begin{array}{l}\text { (5) Scored good } \\
\text { marks in } \\
\text { Innovation } \\
\text { Ecosystem }\end{array}$ & & & \\
\hline 3 & $\begin{array}{l}\text { BANASTHALI } \\
\text { VIDYAPITH } \\
\text { Rajasthan, }\end{array}$ & $\begin{array}{l}\text { (1) Scored full } \\
\text { marks in } \\
\text { Innovation } \\
\text { Ecosystem. } \\
\text { (2) Scored full } \\
\text { marks in } \\
\text { Consultancy. } \\
\text { (3) Scored full } \\
\text { marks in } \\
\text { Extension } \\
\text { Activities. } \\
\text { (4) Scored full } \\
\text { marks in } \\
\text { Collaboration. } \\
\text { (5) Scored good } \\
\text { marks in } \\
\text { Resource } \\
\text { Mobilization for } \\
\text { Research. }\end{array}$ & $\begin{array}{l}\text { (1) Scored less } \\
\text { marks in } \\
\text { Promotion of } \\
\text { Research and } \\
\text { Facilities. } \\
\text { (2) Scored less } \\
\text { marks in } \\
\text { Research } \\
\text { Publications and } \\
\text { Awards. }\end{array}$ & $\begin{array}{l}\text { (1) Good } \\
\text { academic } \\
\text { reputation } \\
\text { (2) Long } \\
\text { standing brand in } \\
\text { the State. } \\
\text { (3) Serving the } \\
\text { local community } \\
\text { especially girls } \\
\text { as Women } \\
\text { University }\end{array}$ & $\begin{array}{l}\text { (1) } \\
\text { Conversion } \\
\text { of Ph.D. } \\
\text { ratio from } \\
70 \% \text { to } \\
100 \% \text {. } \\
\text { (2) } \\
\text { Improving } \\
\text { average } \\
\text { annual } \\
\text { faculty } \\
\text { publication } \\
\text { from current } \\
0.93 \text { to 5.0. }\end{array}$ \\
\hline 4 & $\begin{array}{l}\text { KONERU } \\
\text { LAKSHMAIAH } \\
\text { EDUCATION } \\
\text { FOUNDATION } \\
\text { Andhra Pradesh }\end{array}$ & $\begin{array}{l}\text { (1) Scored full } \\
\text { marks in } \\
\text { Innovation } \\
\text { Ecosystem. } \\
\text { (2) Scored full } \\
\text { marks in } \\
\text { Consultancy. } \\
\text { (3) Scored full } \\
\text { marks in } \\
\text { Extension } \\
\text { Activities. } \\
\text { (4) Scored good } \\
\text { marks in } \\
\text { Resource } \\
\text { Mobilization for } \\
\text { Research. } \\
\text { (4) Scored good } \\
\text { marks in } \\
\text { Collaboration. }\end{array}$ & $\begin{array}{l}\text { (1) Scored less } \\
\text { marks in } \\
\text { Promotion of } \\
\text { Research and } \\
\text { Facilities. } \\
\text { (2) Scored less } \\
\text { marks in } \\
\text { Research } \\
\text { Publications and } \\
\text { Awards. } \\
\text { (3) Lack of } \\
\text { Faculty } \\
\text { motivation } \\
\text { strategies for } \\
\text { enhancing } \\
\text { research } \\
\text { performance. }\end{array}$ & $\begin{array}{l}\text { (1) Self-funded } \\
\text { private } \\
\text { university with } \\
\text { adequate } \\
\text { physical } \\
\text { infrastructure. } \\
\text { (2) Highly } \\
\text { influential } \\
\text { leadership. } \\
\text { (3) Brand image } \\
\text { in the region. }\end{array}$ & $\begin{array}{l}\text { (1) } \\
\text { Conversion } \\
\text { of Ph.D. } \\
\text { ratio from } \\
28 \% \text { to } \\
100 \% \text {. } \\
\text { (2) } \\
\text { Improving } \\
\text { average } \\
\text { annual } \\
\text { faculty } \\
\text { publication } \\
\text { from current } \\
1.25 \text { to 5.0. }\end{array}$ \\
\hline 5 & $\begin{array}{l}\text { INDIRA } \\
\text { GANDHI } \\
\text { NATIONAL } \\
\text { OPEN } \\
\text { UNIVERSITY } \\
\text { Delhi, New Delhi, }\end{array}$ & $\begin{array}{l}\text { (1) Scored full } \\
\text { marks in } \\
\text { Promotion of } \\
\text { Research and } \\
\text { Facilities. } \\
\text { (2) Scored full } \\
\text { marks in } \\
\text { Innovation } \\
\text { Ecosystem. } \\
\text { (3) Scored full } \\
\text { marks in } \\
\text { Collaboration. }\end{array}$ & $\begin{array}{l}\text { (1) Scored less } \\
\text { marks in } \\
\text { Extension } \\
\text { Activities. } \\
\text { (2) Scored less } \\
\text { marks in } \\
\text { Research } \\
\text { Publications and } \\
\text { Awards. } \\
\text { (3) Scored very } \\
\text { less marks in } \\
\text { Resource }\end{array}$ & $\begin{array}{l}\text { (1) Long } \\
\text { standing } \\
\text { reputation. } \\
\text { (2) Only one } \\
\text { open university } \\
\text { serving entire } \\
\text { country. } \\
\text { (3) Influential } \\
\text { Vice-Chancellor. }\end{array}$ & $\begin{array}{l}(1) \\
\text { Conversion } \\
\text { of Ph.D. } \\
\text { ratio from } \\
88 \% \text { to } \\
100 \% . \\
(2) \\
\text { Improving } \\
\text { average } \\
\text { annual } \\
\text { faculty } \\
\text { publication }\end{array}$ \\
\hline
\end{tabular}




\begin{tabular}{|c|c|c|c|c|c|}
\hline & & & $\begin{array}{l}\text { Mobilization for } \\
\text { Research. } \\
\text { (4) Scored very } \\
\text { less marks in } \\
\text { Consultancy. }\end{array}$ & & $\begin{array}{l}\text { from current } \\
2.18 \text { to } 5.0 \text {. }\end{array}$ \\
\hline 6 & $\begin{array}{l}\text { SRM INSTITUTE } \\
\text { OF SCIENCE } \\
\text { AND } \\
\text { TECHNOLOGY } \\
\text { Tamil Nadu, } \\
\text { Chennai, }\end{array}$ & $\begin{array}{l}\text { (1) Scored full } \\
\text { marks in } \\
\text { Promotion of } \\
\text { Research and } \\
\text { Facilities. } \\
\text { (2) Scored full } \\
\text { marks in } \\
\text { Innovation } \\
\text { Ecosystem. } \\
\text { (3) Scored full } \\
\text { marks in } \\
\text { Consultancy. } \\
\text { (4) Scored full } \\
\text { marks in } \\
\text { Extension } \\
\text { Activities. } \\
\text { (5) Scored full } \\
\text { marks in } \\
\text { Collaboration. }\end{array}$ & $\begin{array}{l}\text { (1) Scored less } \\
\text { marks in } \\
\text { Resource } \\
\text { Mobilization for } \\
\text { Research. } \\
\text { (2) Scored very } \\
\text { less marks in } \\
\text { Research } \\
\text { Publications and } \\
\text { Awards. }\end{array}$ & $\begin{array}{l}\text { (1) Huge } \\
\text { physical } \\
\text { infrastructure } \\
\text { and digital } \\
\text { infrastructure. } \\
\text { (2) Large } \\
\text { number of } \\
\text { students from } \\
\text { different States } \\
\text { and Countries. } \\
\text { (3) Has large } \\
\text { number of } \\
\text { faculty members } \\
\text { and if } \\
\text { empowered } \\
\text { suitably can } \\
\text { contribute more } \\
\text { research output. }\end{array}$ & $\begin{array}{l}\text { (1) } \\
\text { Conversion } \\
\text { of Ph.D. } \\
\text { ratio from } \\
32 \% \text { to } \\
100 \% \text {. } \\
(2) \\
\text { Improving } \\
\text { average } \\
\text { annual } \\
\text { faculty } \\
\text { publication } \\
\text { from current } \\
0.82 \text { to } 5.0 .\end{array}$ \\
\hline 7 & $\begin{array}{l}\text { MADURAI } \\
\text { KAMARAJ } \\
\text { UNIVERSITY } \\
\text { Tamil Nadu }\end{array}$ & $\begin{array}{l}\text { (1) Scored full } \\
\text { marks in } \\
\text { Resource } \\
\text { Mobilization for } \\
\text { Research. } \\
\text { (2) Scored full } \\
\text { marks in } \\
\text { Innovation } \\
\text { Ecosystem. } \\
\text { (3) Scored full } \\
\text { marks in Scored } \\
\text { full marks in } \\
\text { Consultancy. } \\
\text { (4) Scored full } \\
\text { marks in } \\
\text { Collaboration. }\end{array}$ & $\begin{array}{l}\text { (1) Scored less } \\
\text { marks in } \\
\text { Research } \\
\text { Publications and } \\
\text { Awards. } \\
\text { (2) Scored very } \\
\text { less marks in } \\
\text { Promotion of } \\
\text { Research and } \\
\text { Facilities. } \\
\text { (3) Scored very } \\
\text { less marks in } \\
\text { Extension } \\
\text { Activities. }\end{array}$ & $\begin{array}{l}\text { (1) Opportunity } \\
\text { to get research } \\
\text { funds from } \\
\text { Central } \\
\text { government and } \\
\text { State } \\
\text { government. } \\
\text { (2) Eminent } \\
\text { researcher as } \\
\text { Vice-chancellor } \\
\text { and role mode. } \\
\text { (3) Large } \\
\text { number of } \\
\text { research } \\
\text { scholars. }\end{array}$ & $\begin{array}{l}\text { (1) } \\
\text { Conversion } \\
\text { of Ph.D. } \\
\text { ratio from } \\
95 \% \text { to } \\
100 \% \text {. } \\
(2) \\
\text { Improving } \\
\text { average } \\
\text { annual } \\
\text { faculty } \\
\text { publication } \\
\text { from current } \\
1.6 \text { to } 5.0 .\end{array}$ \\
\hline 8 & $\begin{array}{l}\text { SRI } \\
\text { RAMACHANDR } \\
\text { A INSTITUTE } \\
\text { OF HIGHER } \\
\text { EDUCATION } \\
\text { AND } \\
\text { RESEARCH } \\
\text { Tamil Nadu }\end{array}$ & $\begin{array}{l}\text { (1) Scored full } \\
\text { marks in } \\
\text { Resource } \\
\text { Mobilization for } \\
\text { Research. } \\
\text { (2) Scored good } \\
\text { marks in } \\
\text { Promotion of } \\
\text { Research and } \\
\text { Facilities. } \\
\text { (3) Scored good } \\
\text { marks in } \\
\text { Extension } \\
\text { Activities. }\end{array}$ & $\begin{array}{l}\text { (1) Scored less } \\
\text { marks in } \\
\text { Innovation } \\
\text { Ecosystem. } \\
\text { Consultancy. } \\
\text { (2) Scored less } \\
\text { marks in } \\
\text { Research } \\
\text { Publications and } \\
\text { Awards. } \\
\text { (3) Scored very } \\
\text { less marks in } \\
\text { Collaboration. }\end{array}$ & $\begin{array}{l}\text { (1) Run by } \\
\text { famous } \\
\text { charitable trust } \\
\text { and hence access } \\
\text { to more research } \\
\text { funds. } \\
\text { (2) University } \\
\text { has center for } \\
\text { research in } \\
\text { medical sciences } \\
\text { and hence more } \\
\text { opportunity for } \\
\text { intensifying } \\
\text { research and } \\
\text { publications. }\end{array}$ & $\begin{array}{l}\text { (1) } \\
\text { Conversion } \\
\text { of Ph.D. } \\
\text { ratio from } \\
77 \% \text { to } \\
100 \% \text {. } \\
(2) \\
\text { Improving } \\
\text { average } \\
\text { annual } \\
\text { faculty } \\
\text { publication } \\
\text { from current } \\
0.98 \text { to 5.0. }\end{array}$ \\
\hline
\end{tabular}




\begin{tabular}{|c|c|c|c|c|c|}
\hline 9 & $\begin{array}{l}\text { SHIVAJI } \\
\text { UNIVERSITY, } \\
\text { Kolhapur, } \\
\text { Maharashtra. }\end{array}$ & $\begin{array}{l}\text { (1) Scored good } \\
\text { marks in } \\
\text { Resource } \\
\text { Mobilization for } \\
\text { Research. } 3.7 \\
\text { (2) Scored full } \\
\text { marks in } \\
\text { Consultancy. } \\
\text { (3) Scored full } \\
\text { marks in } \\
\text { Collaboration. }\end{array}$ & $\begin{array}{l}\text { (1) Scored less } \\
\text { marks in } \\
\text { Extension } \\
\text { Activities. } \\
\text { (2) Scored less } \\
\text { marks in } \\
\text { Research } \\
\text { Publications and } \\
\text { Awards. } \\
\text { (3) Scored less } \\
\text { marks in } \\
\text { Innovation } \\
\text { Ecosystem. } \\
\text { (4) Scored less } \\
\text { marks in } \\
\text { Promotion of } \\
\text { Research and } \\
\text { Facilities. }\end{array}$ & $\begin{array}{l}\text { (1) Being public } \\
\text { university, has } \\
\text { better access to } \\
\text { research funds. } \\
\text { (2) More faculty } \\
\text { members have } \\
\text { research degrees } \\
\text { and hence by } \\
\text { setting targets } \\
\text { and } \\
\text { accountability, } \\
\text { research output } \\
\text { and publications } \\
\text { can be increased. }\end{array}$ & $\begin{array}{l}\text { (1) } \\
\text { Conversion } \\
\text { of Ph.D. } \\
\text { ratio from } \\
81 \% \text { to } \\
100 \% \text {. } \\
(2) \\
\text { Improving } \\
\text { average } \\
\text { annual } \\
\text { faculty } \\
\text { publication } \\
\text { from current } \\
1.88 \text { to } 5.0 .\end{array}$ \\
\hline
\end{tabular}

\section{SUGGESTONS :}

(1) As per the UGC guidelines, universities should appoint only Ph.D. qualified faculty members in their departments, NAAC should adopt a policy that if the number of faculty members having Ph.D. degree is less than a certain level, they will not qualify to get higher letter grade. Accordingly, by referring table 2, the A++ graded universities should have minimum $87 \%$ Ph.D. qualified faculty members as permanent faculty in its role and the NAAC letter grade should go down as the percentage of the number of Ph.D. degree qualified faculty members are lower as suggested in table 23.

Table 23: Proposal to connect Accreditation letter grade with a percentage of Ph.D. qualified faculty members.

\begin{tabular}{|l|l|l|l|l|}
\hline $\begin{array}{l}\text { S. } \\
\text { No. }\end{array}$ & $\begin{array}{l}\text { Cumulative } \\
\text { Grade Point } \\
\text { Average (CGPA) }\end{array}$ & $\begin{array}{l}\text { Letter grade \& } \\
\text { Status }\end{array}$ & $\begin{array}{l}\text { Percentage \% of } \\
\text { Marks }\end{array}$ & $\begin{array}{l}\text { Minimum Percentage of } \\
\text { Faculty Members required } \\
\text { with Ph.D. degree }\end{array}$ \\
\hline 1 & $3.51-4.00$ & A++ (Accredited) & $(\geq 87.6 \%)$ & $87 \%$ \\
\hline 2 & $3.26-3.50$ & A+ (Accredited) & $(81.5 \%-87.5 \%)$ & $81 \%$ \\
\hline 3 & $3.01-3.25$ & A (Accredited) & $(75.25 \%-81 \%)$ & $75 \%$ \\
\hline 4 & $2.76-3.00$ & B++ (Accredited) & $(69 \%-75 \%)$ & $69 \%$ \\
\hline 5 & $2.51-2.75$ & B+ (Accredited) & $\begin{array}{l}(62.75 \% \\
68.75 \%)\end{array}$ & $62 \%$ \\
\hline 6 & $2.01-2.50$ & B (Accredited) & $(50.25 \%-62.5 \%)$ & $50 \%$ \\
\hline 7 & $1.51-2.00$ & C (Accredited) & $(37.75 \%-50 \%)$ & $36 \%$ \\
\hline 8 & $0.00-1.50$ & D (Not Accredited) & $(\leq 37.5 \%)$ & 0 to $35 \%$ \\
\hline
\end{tabular}

(2) The faculty members should publish minimum two scholarly research papers or patents as the first authors per year so that university research productivity will increase and it can compete with global universities. NAAC grading should look into the number of scholarly publications per year per faculty members. For example, A and higher letter grade universities should have at least 4 average faculty publications per year, B grade universities should have at least 3 average faculty publications per year and $\mathrm{C}$ grade universities should have at least 2 average faculty publications per year. This rule should be equally applicable at all cadres including Vice-Chancellor of the university. Such universities can be called research-intensive universities.

(3) NAAC accreditation system should promote open access publications of research results of universities by keeping copyright with researchers. This allows researchers to apply patents of their inventions after publishing it.

(4) The Vice-Chancellors should be role models for researchers and their contribution to research and its output should be considered in accreditation scoring system. It is suggested that Assistant Professors 
should have last 5 years $\mathrm{H}$-index at least in the range of 5 to 10 , Associate professors should have last 5 years H-Index at least in the range of 10 to 15, Professors should have last 5 years H-Index 15 to 20, and Vice Chancellors should have last 5 years H-Index at least 20 and above to be qualified to become role models for researchers of a university. But as per table 18, except the Vice-chancellor/Director of Indian Institute of Science, Bangalore, all other Vice-chancellors have last 5 years H-index less than 20 and hence disqualified to become Role models to the researchers of the university.

\section{LIMITATIONS :}

This study of comparison of NAAC A++ grade universities is restricted to only the universities that obtained A++ grade from National Assessment and Accreditation Council, announced in their website as per the new accreditation framework, as of 30/04/2021, and the data used for the analysis are also collected from the Self-study Report, Peer Team Report, and Grade Report of respective universities kept for public reference (https://assessmentonline.naac.gov.in). Other data are obtained from Google Scholar searches. Authors are not responsible for any variations in the data provided by these organizations through the NAAC website.

\section{CONCLUSION :}

Developing and Maintaining quality in higher education is a very important aspect of the sustainability of universities. Accreditation process developed systematically with tangible metrics and transparent assessment methods in higher education by accreditation agencies will enhance the credibility of both accreditation yardstick and of the accredited universities. In the process of continuous improvement of the assessment of universities and colleges, the National Assessment and Accreditation Council (NAAC) of India has developed a seven-criteria assessment model to rate them using various letter grades. This paper analysed nine A++ graded Indian universities under the new assessment framework as of the $30^{\text {th }}$ of April 2021. Further emphasis is given to research and publication performance of these universities and their average annual research productivities are measured and compared using $\mathrm{ABC}$ model of Organizational research productivity. It is found that the low research performance of these universities affected their overall accreditation credits. Some of the disparities in the offered credits are also observed during comparison and the reasons for such disparities are also predicted. It is argued that the Vice-Chancellor or Director of the university has to be a role model in active research and publication in order to motivate and to set targets to others for enhanced performance.

\section{REFERENCES :}

[1] National Assessment and Accreditation Council, India. http://naac.gov.in/index.php/aboutus\#organization

[2] Alhat, S. S. (2020). Understanding Revised NAAC Grading Pattern. International Journal of Arts, Science and Humanities, 8(1), 57-60.

[3] Patil, J. (2018). Paradigm Shift in Indian Higher Education Accreditation. In Capacity Building for Next Generation Quality Assurance in Higher Education (pp. 76-89).

[4] Menon, S. R., \& Shyam, A. V. Quality Assessment of Higher Education Institutions - A Critical Analysis of NAAC Data. 1-14. https://www.amrita.edu/sites/default/files/quality-assessment-ofhigher-education-institutions-a-critical-analysis-of-naac-data.pdf

[5] Kumar, P., Shukla, B., \& Passey, D. (2020). Impact of Accreditation on Quality and Excellence of Higher Education Institutions. Investigación Operacional, 41(2), 151-167.

[6] Ghatole, S. M., \& Dahikar, P. B. (2021). NAAC Accreditation: A Quality Initiative Reform in Indian Higher Education. The Research Journal (TRJ): A Unit of I2OR, 7(1), 42-47.

[7] Iyer, S. R. (2019). Quality Enhancement of State Private Universities Through NAAC Accreditation Process in Indian Context. Sankalpa, 9(2), 21-26.

[8] Ravikumar, K., Samanta, S., Rath, A. K., \& Srinivasaragavan, S. (2021). Quality Assessment of Indian Universities: An Analytical Study of NAAC Accreditation Scores. Psychology and Education Journal, 58(2), 5903-5914. 
[9] Gholap, P., \& Kushare, P. (2019). A Comparative study of Accreditation Grades of NAAC vis-avis NBA for Quality Improvement of Higher Education in India. International Journal of 360 Management Review, 7(02), 72-84.

[10] Miglani, N., Saha, R., \& Parihar, R. S. (2017). A Graph Theoretic Approach for Quantitative Evaluation of NAAC Accreditation Criteria for the Indian University. International Journal of Industrial and Manufacturing Engineering, 11(7), 1955-1960.

[11] Pawar, N. R., \& Gundawar, D. A. (2017). Importance of Research for NAAC Accreditation. Seminar Proceedings, pp 24-25, ISBN 978-93-5268-073-3.

[12] Sibi, K. J. (2020). Challenges and Opportunities of HEIS Towards Quality Excellence and NAAC Assessment and Accreditation in Revised Manual. Our Heritage, 68(60), 74-81.

[13] Joshi, V. (2018). Study of Dimensions of 'Curricular Aspects Criteria' of the Accreditation of Higher Education Institution by NAAC. Available at SSRN 3108433. Available at SSRN: https://ssrn.com/abstract=3108433 or http://dx.doi.org/10.2139/ssrn.3108433.

[14] Manimala, M. J., Wasdani, K. P., \& Vijaygopal, A. (2020). Facilitation and Regulation of Educational Institutions: The Role of Accreditation. Vikalpa, 45(1), 7-24.

[15] Amutha, S., \& Ponmudiraj, B. S. (2019). A Symbiotic Analysis of NAAC Accredited Higher Education Institutions. Journal of the Gujarat Research Society, 21(4), 57-69.

[16] Aithal, P. S., \& Kumar, P. M. (2016). ABC model of research productivity and higher educational institutional ranking. International Journal of Education and Management Engineering (IJEME), 6(6), 74-84.

[17] Aithal, P. S., \& Kumar, P. M. (2016). Application of Theory A on ABC Model to enhance Organizational Research Productivity in Higher Education. International Journal of Advanced Trends in Engineering and Technology (IJATET), 1(1), 142-150.

[18] Aithal, P. S., Shailashree, V. T, \& Suresh Kumar, P. M. (2016). Analysis of ABC Model of Annual Research Productivity using ABCD Framework. International Journal of Current Research and Modern Education (IJCRME), 1(1), 846-858.

[19] Aithal, P. S., \& Kumar, P. M. (2017). Interconnecting Theory A and ABC Model of Organizational Performance. International Journal of Management, Technology and Social Sciences (IJMTS), Srinivas Publishers, 1(1), 1-13.

[20] Aithal, P. S. (2016). Research Performance Analysis of Some Indian Top Business Schools Using ABC Model. International Journal of Computational Research and Development, 1(1), 70-83.

[21]Aithal, P. S. (2016). How to Increase Research Productivity in Higher Educational InstitutionsSIMS Model. International Journal of Scientific Research and Modern Education (IJSRME), 1(1), 447-458.

[22] Aithal, P. S. (2016). Study of Research Productivity in World Top Business Schools. International Journal of Engineering Research and Modern Education (IJERME), 1(1), 629-644.

[23] Aithal, P. S., \& Kumar, P. M. (2016). Organizational behaviour in 21st century-'Theory A' for managing people for performance. IOSR Journal of Business and Management (IOSR$J B M), 18(7), 126-134$.

[24] Aithal, S., \& Kumar, S. (2016). Comparative Analysis of Theory X, Theory Y, Theory Z, and Theory A for Managing People and Performance. International Journal of Scientific Research and Modern Education (IJSRME), 1(1), 803-812.

[25] Aithal, P. S., \& Kumar, P. M. (2019). Autonomy in Higher Education-Towards an Accountability Management Model. International Journal of Management \& Development, 6(10), 166-175.

[26] Aithal, P. S., \& Kumar, P. M. (2016). CCE Approach through ABCD Analysis of 'Theory A' on Organizational Performance. International Journal of Current Research and Modern Education (IJCRME), 1(2), 169-185. 
[27] Aithal, P. S., \& Kumar, P. M. (2017). Interconnecting Theory A and ABC Model of Organizational Performance. International Journal of Management, Technology and Social Sciences (IJMTS), Srinivas Publishers, 1(1), 1-13.

[28] Aithal, P. S., \& Kumar, P. M. (2016). Application of Theory A on ABC Model to enhance Organizational Research Productivity in Higher Education. International Journal of Advanced Trends in Engineering and Technology (IJATET), 1(1), 142-150.

[29] Aithal, P. S., \& Kumar, P. M. (2017). Integrating Theory A and six thinking hats technique for improved organizational performance. International Journal of Applied Engineering and Management Letters (IJAEML), 1(2), 66-77.

[30] Aithal, P. S., Kumar, P., \& Dillon, M. (2018). How to Improve the Employee Productivity of Banking System in India-A Theory of Accountability Based Analysis. International Journal of Management, Technology, and Social Sciences (IJMTS), 3(2), 87-99.

[31] Aithal, P. S. (2016). Excellence in Individual Research \& Publications: Examining the Active Role of Role models (Deans) of World Top Business Schools. International Journal of Engineering Research and Modern Education (IJERME), 1(2), 179-199.

[32] Aithal, P. S. (2018). Effect of Role Models-A Critical Study on the Recent Research Contribution of Vice-Chancellors of Selected Private Universities in India. International Journal of Management, Technology, and Social Sciences (IJMTS), 3(1), 118-139.

[33] Aithal, P. S. (2016). Excellence in Individual Research \& Publications: Examining the Active Role of Role models (Deans) of World Top Business Schools. International Journal of Engineering Research and Modern Education (IJERME), 1(2), 179-199.

[34] Aithal, P. S. (2018). How to boost faculty research performance in HEI's to improve intellectual property by integrating it with faculty compensation-A 'theory of accountability' based framework. International Journal of Management, Technology, and Social Sciences (IJMTS), 3(2), 130-151.

[35] Aithal, P. S., \& Aithal, S. (2019). Building World-Class Universities: Some Insights \& Predictions. Building World-Class Universities: Some Insights \& Predictions. International Journal of Management, Technology, and Social Sciences (IJMTS), 4(2), 13-35.

[36] Aithal, P. S., \& Aithal, S. (2020). Analysis of the Indian National Education Policy 2020 towards Achieving its Objectives. International Journal of Management, Technology, and Social Sciences (IJMTS), 5(2), 19-41.

[37] Aithal, P. S., \& Aithal, S. (2020). Implementation Strategies of Higher Education Part of National Education Policy 2020 of India towards Achieving its Objectives. International Journal of Management, Technology, and Social Sciences (IJMTS), 5(2), 283-325.

[38] Aithal, P. S., \& Kumar, P. M. (2019). Autonomy in Higher Education-Towards an Accountability Management Model. International Journal of Management \& Development, 6(10), 166-175.

[39] Aithal, P. S., \& Kumar, P. M. (2015). Black Ocean Strategy-A Probe into a new type of Strategy used for Organizational Success. GE-International Journal of Management Research (GEIJMR), 3(8), 45-65.

[40] Aithal, P. S., \& Kumar, P. M. (2015). Applying SWOC Analysis to an Institution of Higher Education. International Journal of Management, IT and Engineering, 5(7), 231-247.

[41] Aithal, P. S., \& Aithal, S. (2019). New Directions in Scholarly Research-Some Fearless Innovations \& Predictions for 21st Century Research. International Journal of Management, Technology, and Social Sciences (IJMTS), 4(1), 1-19. 